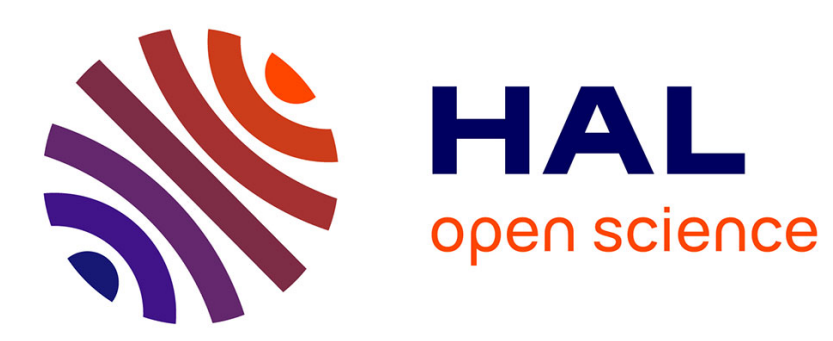

\title{
Regional magnetic and gravity anomaly correlations of the Southern Tyrrhenian Sea
}

\author{
R. de Ritis, G. Ventura, M. Chiappini, R. Carluccio, R. von Frese
}

\section{To cite this version:}

R. de Ritis, G. Ventura, M. Chiappini, R. Carluccio, R. von Frese. Regional magnetic and gravity anomaly correlations of the Southern Tyrrhenian Sea. Physics of the Earth and Planetary Interiors, 2010, 181 (1-2), pp.27. 10.1016/j.pepi.2010.04.003 . hal-00645173

\section{HAL Id: hal-00645173 \\ https://hal.science/hal-00645173}

Submitted on 27 Nov 2011

HAL is a multi-disciplinary open access archive for the deposit and dissemination of scientific research documents, whether they are published or not. The documents may come from teaching and research institutions in France or abroad, or from public or private research centers.
L'archive ouverte pluridisciplinaire $\mathbf{H A L}$, est destinée au dépôt et à la diffusion de documents scientifiques de niveau recherche, publiés ou non, émanant des établissements d'enseignement et de recherche français ou étrangers, des laboratoires publics ou privés. 


\section{Accepted Manuscript}

Title: Regional magnetic and gravity anomaly correlations of the Southern Tyrrhenian Sea

Authors: R. De Ritis, G. Ventura, M. Chiappini, R. Carluccio, R. Von Frese

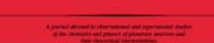

PII:

S0031-9201(10)00071-3

DOI: doi:10.1016/j.pepi.2010.04.003

Reference: PEPI 5276

To appear in: $\quad$ Physics of the Earth and Planetary Interiors

Received date: $\quad$ 5-2-2010

Revised date: $\quad$ 25-3-2010

Accepted date: $\quad$ 6-4-2010

Please cite this article as: De Ritis, R., Ventura, G., Chiappini, M., Carluccio, R., Von Frese, R., Regional magnetic and gravity anomaly correlations of the Southern Tyrrhenian Sea, Physics of the Earth and Planetary Interiors (2008), doi:10.1016/j.pepi.2010.04.003

This is a PDF file of an unedited manuscript that has been accepted for publication. As a service to our customers we are providing this early version of the manuscript. The manuscript will undergo copyediting, typesetting, and review of the resulting proof before it is published in its final form. Please note that during the production process errors may be discovered which could affect the content, and all legal disclaimers that apply to the journal pertain. 


\title{
Regional magnetic and gravity anomaly correlations of the Southern Tyrrhenian Sea
}

\author{
De Ritis R. ${ }^{1}$, Ventura G. ${ }^{1}$, Chiappini M. ${ }^{1}$, Carluccio R. ${ }^{1}$, Von Frese R. ${ }^{2}$ \\ ${ }^{1}$ Istituto Nazionale di Geofisica e Vulcanologia, 00143 Roma, Italy \\ ${ }^{2}$ School of Earth Science, Ohio State University, Columbus Ohio 43210, USA
}

\section{Abstract}

The complex magnetic and gravity anomaly fields of the Southern Tyrrhenian Sea provide a record of the complicated properties and evolution of the underlying crust. Geologic interpretation of these anomalies is hindered by the effects of anomaly superposition and source ambiguity inherent to potential field analysis. A common approach to minimizing interpretational ambiguities is to consider analyses of anomaly correlations. Spectral correlation filters are used to separate positively and negatively correlated anomaly features based on the correlation coefficient given by the cosine of the phase difference between common wavenumber components. This procedure is applied to reduced-to-pole magnetic and first vertical derivative gravity anomalies for mapping correlative crustal magnetization and density contrasts. Adding and subtracting the standardized outputs of the filters yield summed (SLFI) and differenced (DLFI) local favourability indices that respectively highlight positive and negative feature correlations in the anomaly data sets. Correlative maxima mainly reflect volcanic structures, and secondarily intrusive bodies and pre-Tortonian carbonates of the Maghrebian chain and the basement rocks of the Sardinia eastern margin. Correlative minima mostly mark sediment-filled peri-Tyrrhenian structural basins related to the Pliocene extensional tectonics, and intra-slope marine depressions related to post-Pliocene and still active compressional tectonics off northern Sicily. Prominent inverse anomaly correlations mainly reflect crustal features around the southern margin of the Tyrrhenian Sea that include higher density, lower magnetization pelagic-to-terrigenous and flysch-type nappes of the Sicilian-Maghrebian chain, as well as lower density, higher magnetization sediments filling depressions of the chain, and syn-rift sediments of south eastern Sardinia.

Keywords: magnetism, gravity, modelling, back-arc basin, volcanism, tectonics, Tyrrhenian Sea 


\section{Introduction}

As part of the African-European plate boundary, the Southern Tyrrhenian Sea exhibits considerable tectonic complexity (Figure 1). This boundary hosts the Apennines and Maghrebides mountain belts, and the Marsili, Vavilov, and Magnaghi oceanic-like basins, as well as active volcanoes such as intraplate Etna, and the subduction-related Stromboli and Vulcano of the Aeolian Arc (Malinverno and Ryan, 1986; Mascle et al., 1988; Kastens et al., 1988; Serri, 1990; Patacca et al., 1993). The region also features destructive seismic activity that included the massive $\mathrm{M}=7.2$ Messina earthquake of 1908 .

The crustal evolution of the Southern Tyrrhenian Sea in the last $10 \mathrm{Ma}$ is dominated by the slow convergence of the African and European plates, fast subduction roll-back below the southern Apennines and Sicily, and sea-floor spreading in the Tyrrhenian Sea (Carminati et al., 1998; Faccenna et al., 2003; Speranza et al., 2003). Because of the volcanic and earthquake hazards, considerable efforts have been carried out to characterize the evolution and active geodynamic processes in the Southern Tyrrhenian Sea and surrounding area (e.g., Faggioni et al., 1995; Cella et al., 1998; Cimini, 1999; Doglioni et al., 1999; Gvirtzman and Nur, 1999; Pepe et al., 2000; Savelli, 2001, 2002; Marani and Trua, 2002; Hollenstein et al., 2003; Rosenbaum and Lister, 2004; Sartori, 2005; Marotta et al., 2007; Montuori et al., 2007; Chiarabba et al., 2008). Several studies have focused on the more regional and deeper features of the Southern Tyrrhenian Sea (e.g., Cella et al., 1998; Marotta et al., 2007; Monturi et al., 2007; Chiarabba et al., 2008), whereas more localized geological investigations have characterized the offshore areas of Northern Sicily (Pepe et al., 2003), the Aeolian islands (De Astis et al., 2003), and the Marsili Basin (Nicolosi et al., 2006).

The magnetic and gravity anomalies shown respectively in Figures $\mathbf{2 . a}$ and $\mathbf{2 . b}$ facilitate integrating the regional and local results from these studies. They also provide key constraints for understanding the geologic features and evolution of the study region because the crust is mostly covered by sea water. However, establishing the geological significance of the potential field observations is difficult due to the considerable spatial complexity of the anomaly patterns. A common approach to reducing this interpretational complexity is to investigate the anomaly correlations (e.g., von Frese et al., 1982; 1997a; 1997b).

For the Southern Tyrrhenian Sea, numerous crustal sources of common magnetization and density contrasts may be anticipated. For example, positively correlated anomalies can reflect the effects of sedimentary rocks, mafic intrusions, and volcanic terrain produced in the normal polarity geomagnetic field, whereas negatively correlated anomalies may characterize sources 
83

emplaced in the reversed polarity field. Table 1 generalizes further correlative crustal features of the Southern Tyrrhenian Sea. For the source of both magnetic and gravimetric fields, Poisson's relation equates the derivative of the gravity effect in the direction of magnetization to the magnetic effect and thus establishes the quantitative basis for identifying correlative magnetic and gravity anomalies (e.g., von Frese et al., 1982; 1997a; 1997b).

In this study, we investigate the utility of the anomaly correlations for enhancing our understanding of the crustal features of the Southern Tyrrhenian Sea. In the sections below, we outline the geological context for interpreting the anomalies and describe our anomaly correlation methodology. We also investigate the correlative anomalies for new insights on the crust of the Southern Tyrrhenian Sea in light of the available geological, seismic, and other geophysical information (e.g., Finetti, 2005 and references therein).

\section{Geological setting of the Southern Tyrrhenian Sea}

The Tyrrhenian Sea is a back-arc basin related to the subduction of the W-to-NW dipping African lithospheric slab under the Apennines, Calabrian Arc, and Maghrebides orogenic belts (Malinverno and Ryan, 1986; Patacca and Scandone, 1989; Gvirtzman and Nur, 2001; Faccenna et al., 2001). The Northern Tyrrhenian Sea north of $41^{\circ} \mathrm{N}$ (Figure 1a) is bounded by Corsica, Sardinia, and the Northern Apennines, and underlain by thinned continental crust. The Southern Tyrrhenian Sea south of $41^{\circ} \mathrm{N}$ is surrounded by the Southern Apennines, Calabrian Arc, and Maghrebides. It includes stretched fragments of the continental crust and the deep (up to $3000 \mathrm{~m}$ b.s.1.), relatively young ( $<5 \mathrm{Ma}$ ) Vavilov and Marsili oceanic basins (Kastens et al., 1988). Back-arc seafloor spreading is evident in these basins, which have Moho depths of about $10 \mathrm{~km}$ (Cella et al., 1998). Seismic tomography and earthquake hypocenter depths up to $300 \mathrm{~km}$ depict the $70-75^{\circ} \mathrm{NW}$-dipping Ionian slab below the Calabrian Arc (Spakman et al., 1993; Piromallo and Morelli, 1997; De Astis et al., 2003; Goes et al., 2006).

The eastern Sardinia margin exposes Tortonian syn-rift sediments (Bartole, 1995; Sartori et al., 2001) and records the main opening phase of the Southern Tyrrhenian Sea (Sartori et al., 2001). The extensional tectonics moved eastwards with the migration of the thrust front of the Southern Apennines belt. Allochthonous, late Tortonian sediments have also been reported from the rifted margin of northern Sicily (Pepe et al., 2000; Rosenbaum and Lister, 2004). 
The southwestern margin of the Southern Tyrrhenian Sea opened along the WSWENE striking Drepano-Elimi shear zone. Extension processes culminated with the development of seamounts and seafloor spreading in the Vavilov (5-4 Ma) and Marsili Basins (3-2 Ma) (Kastens et al., 1988). Additional igneous activity included subduction-related calcalkaline-to-shoshonitic magmatic events, and intraplate alkaline and MORB-type magmatism (Argnani and Savelli, 2001; Savelli, 2002). The oldest volcanics located east of Sardinia date to ca. 13-7 Ma. Progressive magmatism marked by the emplacement of the Aceste ( $5 \mathrm{Ma})$ and Anchise (3.5-5.3 Ma) seamounts reflects the E-SE migration of the subduction zone. Intraplate alkaline rocks outcrop on the islands of Quirra ( $3 \mathrm{Ma})$ and Ustica (0.75-0.13 Ma), and MORB-like volcanics make up the Marsili Basin floor.

The northern offshore evolution of Sicily and Calabria involved episodes of contraction and extension from early Miocene to the present. The areas include the structural Solunto High (e.g., Pepe et al., 2005) and the deep sedimentary peri-Tyrrhenian Paola, Gioia and Cefalù Basins. These basins are bounded by the Maghrebian thrusts to the south, and the Drepano-Elimi thrust zone to the northwest (Sulli, 2000).

The Sicily margin is composed of Maghrebian and Calabrian units. The Maghrebian units consist of SE-vergent, tectonic stacks formed by Meso-Cenozoic platform carbonates (Catalano et al., 1985), nappes of Mesozoic-Paleogene basinal carbonates, and pelagic-toterrigenous (Sicilide) and Miocene flysch-type nappes. The Calabrian units outcrop in northeastern Sicily and Calabria (Giunta et al., 1992). Their western extension offshore has also been documented in the southwestern sector of the Tyrrhenian Basin (Sartori et al., 2001). These units consist of Hercynian basement rocks and thick wedges of AquitanianEarly Burdigalian deep-sea turbidites (Torelli et al., 1991).

In the western sector of the margin, the Calabrian units overthrusted the Maghrebian units along the Drepano-Elimi zone (Figures 1.b, 1.c), forming the arc-shaped Elimi chain (Compagnoni et al., 1989). Upper Neogene-to-recent sediments are concentrated within the peri-Tyrrhenian extensional basins. The basin deposits include evaporitic, hemipelagic, terrigenous, and volcanoclastic sediments (Fabbri et al., 1981; Pepe et al., 2003). Strike-slip faults striking NW-SE separate the intra-slope basins (Nigro and Sulli, 1995; Del Ben and Guarnieri, 2000).

The extensional tectonics forming the basins started in Tortonian times (Fabbri et al., 1981; Barone et al., 1982). During the Pliocene, a contractional event formed the intra-slope basins (Catalano et al., 2002; Pepe et al., 2003) and NE-SW thrusts developed. In middle 
controlled the coastal morphology of northern Sicily. Earthquake focal mechanisms show thrusting along the northern Sicily margin that reflects a N-S compression (Montone et al., 1999) related to the Africa-Europe convergence. To the east of the Tindari-Letojanni fault, which bisects the Aeolian volcanoes, an extensional stress field striking NW-SE is active. Such stress field is related to local mantle upwelling processes occurring above the subducting slab. (De Astis et al., 2003). Aeolian volcanism is due to this extensional strain related to the post-1-0.7 Ma slab rollback beneath the Calabrian Arc (Westaway, 1993; Gvirtzman and Nur, 1999; 2001). The WNW-ESE striking, Drepano-Elimi zone controlled the SE migration of the fore- and back-arc systems and the active subduction front from Early Pliocene to the Pleistocene. Delamination of the Calabrian Arc terminated the early phases of the Aeolian volcanic activity at ca. 1.3 Ma.

The tectonically active crust of the Southern Tyrrhenian Sea hosts a complex spectrum of magnetic and gravity anomalies. Geological interpretation of an individual anomaly is hindered by the effect of anomaly superposition and the source ambiguity that is inherent to the analysis of potential fields. Thus, a common approach to minimizing these interpretation limitations is to evaluate the correlation between anomalous magnetic and gravity potential fields (e.g., von Frese et al., 1982; 1997a; 1997b). To facilitate geological assessments of the anomaly correlations, we subdivided the study area into the five sectors shown in Figure 1c, which include: (A) the sediment covered northern Sicily marine sector to the Drepano-Elimi thrust zone, (B) the south western Tyrrhenian Sea sector west of Ustica Island and north of the Drepano-Elimi thrust zone, (C) the Marsili Basin sector, (D) the Aeolian Islands and seamounts, and (E) the Drepano-Elimi thrust zone.

In the next section, we describe the digital databases used to assess the magnetic and gravity anomaly correlations in the five sectors of the study area. In subsequent sections, we describe the application of spectral correlation filtering to the magnetic and gravity anomalies of the study area and discuss the geological implications of the extracted anomaly correlations.

\section{The digital databases}

For this study, we assembled a Digital Elevation Model (DEM) from available bathymetric and terrestrial relief observations, and magnetic and gravity anomaly grids. The 3 $\mathrm{km} \times 3 \mathrm{~km}$ DEM in Figure 1c was extracted from the $5, \times 5$, ETOPO5 digital database (National Geophysical Data Cener, NOAA). 
The total intensity magnetic anomaly data (Figure 2.a) were obtained from a digital database compiled by the Italian National Institute for Geophysics (formerly the ING; now the INGV) from marine surveys conducted between 1965 and 1972, and terrestrial surveys completed in the 1980's (Chiappini et al., 2000). These magnetic anomalies were gridded at the interval of $3 \mathrm{~km}$ (Chiappini et al., 2000).

The free-air gravity anomaly data (Figure 2.b) were derived mostly from the marine satellite altimetry obtained by the GEOSAT and ERS-1 missions supplemented by terrestrial and shipborne gravity observations (Sandwell and Smith, 1997). These data that elaborated a density model showing the distribution of the oceanic crust in the region (Caratori et al., 2008) were also gridded at the interval of $3 \mathrm{~km}$ (Sandwell and Smith, 1997). We used free air anomaly since our analysis is conducted above all sources including the crustal terrain and is basically a marine application where the free-air anomaly is commonly used in place of the Bouguer anomaly. Using the free-air rather than the Bouguer anomaly also minimizes corrupting the analysis with errors related to our poor understanding of the densities of the underlying terrain.

The DEM and magnetic and gravity anomaly grids provide constraints for understanding the geological properties of the largely submerged crust of the Southern Tyrrhenian Sea. The correlation of potential anomalies in particular is a standard approach to geological and geophysical interpretation because their combined analysis tends to decrease possible alternative interpretations (e.g., von Frese et al., 1982; 1997a; 1997b). The next section describes the spectral approach that was used to quantify correlative anomaly features in the magnetic and gravity data of the Southern Tyrrhenian Sea.

\section{Correlation analysis}

Graphical in combination with spectral techniques were implemented to quantify correlations between the geopotential field anomalies (von Frese et al., 1997a; 1997b). The anomalies were first co-registered at common grid coordinates and then transformed into components that accord with the Poisson relation (e.g., von Frese et al., 1997b)

$$
\Delta T(r)=[\Delta m /(G \Delta \sigma)][d \Delta g / d r]
$$

where $\Delta T(r)$ is the total intensity anomaly reduced to-the-pole (RTP), $\Delta m$ and $\Delta \sigma$ are the respective contrasts of the induced magnetization and density of the source, $G$ is the universal 
gravitational constant, and $d \Delta g / d r$ is the first vertical or radial $(r)$ derivative of the gravity anomaly $(\Delta g)$. In particular, the RTP-anomalies $\Delta T(r)$ were computed for the mean IGRF inclination $\left(44^{\circ} \mathrm{N}\right)$ and declination $\left(2^{\circ} \mathrm{E}\right)$ of the study area. Both $\Delta T(r)$ and $d \Delta g / d r$ estimates were evaluated at $3 \mathrm{~km}$ above sea level over common grid coordinates using standard spectral filters (e.g., Blakely, 1996). In addition, we remark that our topic is to find correlations between the magnetic and gravity fields. According to equation 1, when a correlation between the RTP and the First Vertical Derivative (FVD) gravity is found, then such correlation is related to the same source. Therefore, no assumptions are needed for density and magnetization values of the source.

The crustal geology is subjacent to the $3-\mathrm{km}$ altitude anomaly grids of the correlation analysis. Thus, the anomaly correlations can reflect correlative magnetization and density contrasts from bathymetric and topographic relief, as well as the contrasts within this relief and deeper regions of the crust. The inductive components in the RTP magnetic anomalies are completely in phase with any related FVD gravity anomalies. However, the superposed effects of the poorly understood remanent crustal magnetizations within the study region clearly can complicate these anomaly correlations. Thus, this study also offers a significant opportunity to assess the utility of the Tyrrhenian Sea anomaly correlations for interpreting the underwater terrain and deeper crustal components in magnetic anomalies with multiple sources of magnetization.

Every remanently magnetized crustal source also produces inductive components in the geomagnetic field. Thus, the RTP transformation always enhances crustal magnetic anomaly correlations with gravity anomalies because the magnetic anomaly is the superposition of induced and remanent effects. To help illustrate the possible interpretational advantages of these anomaly correlations, we modeled the complex geopotential field effects of a part of the study region that includes Ustica Island and the nearby seamounts as shown in Figure 3. The magnetic anomalies of these features are complicated by the presence of volcanics with reversed magnetization.

The shaded relief image in Figure 3a gives the adopted crustal thicknesses down to -2 $\mathrm{km}$ below sea level that were modeled over the study's observation grid for the total field and RTP magnetic effects in Figures $\mathbf{3 b}$ and $\mathbf{3 c}$, respectively. The modeled magnetization parameters involved the uniform induced intensity of $2.8 \mathrm{~A} / \mathrm{m}$, and $54^{\circ} \mathrm{N}$ inclination and $2^{\circ} \mathrm{E}$ declination for the total field effects and $90^{\circ}$ inclination for the RTP effects. Relative to the total field effects, the RTP effects are shifted northwards and centered over the crustal 
sources. These effects can be seen in reference to the $-1.3 \mathrm{~km}$ bathymetric contour that is colored red in Figure 3a and white in the anomaly maps (Figs. 3b-g).

The southward shift of the total field effects minimizes their spatial correlation with the gravity effects that are centered over the crustal sources as shown in Figure 3d. Accordingly, the gravity effects, which were modeled using the uniform density of 3.000 $\mathrm{kg} / \mathrm{m}^{3}$, have the correlation coefficient (CC) of only 0.58 with the total field magnetic effects. However, the FVD gravity effects (Figure 3e) are correlated at $\mathrm{CC}=0.99$ with the RTP magnetic effects (Figure 3c) because they both have essentially identical phase properties within computational round-off error.

Extensive volcanic rocks in the study area suggest remanent magnetization effects are also possible that may degrade these anomaly correlations. For example, the Ustica volcanic edifice is in a sedimentary basin containing Kabilian and Apennine Units with ages in the range 0.73-0.13 Ma (Savelli, 2001), and thus magnetized during both normal and reversed polarity chrons. To simulate the remanent condition, we included the magnetization effects of an extended tabular body centered on the eastern Ustica volcano $\left(38.32^{\circ} \mathrm{N}, 13.40^{\circ} \mathrm{E}\right)$. The top of the $5 \mathrm{~km} \times 7 \mathrm{~km}$ body was taken at $-2.700 \mathrm{~m}$ and dipped $30^{\circ} \mathrm{E}$ to the depth of $-4.200 \mathrm{~m}$. The effects of this body were computed for the inductive intensity of $0.70 \mathrm{~A} / \mathrm{m}$ at $54^{\circ} \mathrm{N}$ inclination and $2^{\circ} \mathrm{E}$ declination, and the remanent intensity of $1.6 \mathrm{~A} / \mathrm{m}$ (e.g., BlancoMontenegro et al., 2006) at $-54^{\circ} \mathrm{S}$ inclination and $-2^{\circ} \mathrm{W}$ declination.

When integrated with the terrain's induced magnetic effects (Figure 3b), the correlation of the resulting total field effects in Figure 3f with the terrain's gravity effects (Figure 3d) is significantly degraded to $\mathrm{CC}=0.37$. However, the correlation is greatly improved to CC $=0.70$ for the FVD gravity effects (Figure 3e) and the related RTP effects in Figure 3g that were computed assuming all the induced components at vertical inclination. These results illustrate the possible benefits from the RTP magnetic and FVD gravity transformations for resolving common sources of magnetization and density contrasts, even where complicated by remanent magnetic effects. However, the existence of correlated anomalies clearly cannot guarantee a common source because of the non-uniqueness of potential field analysis.

Returning to the South Tyrrhenian Sea study area, Figures $\mathbf{2 a}$ and $\mathbf{2 b}$ were transformed into the normalized RTP magnetic and FVD free-air gravity anomalies given in

271 Figures $\mathbf{4 a}$ and $\mathbf{4 b}$, respectively. The transformed anomalies were normalized to enhance the 272 graphical perception of correlative anomaly features (e.g., von Frese et al., 1997a). 273 Specifically, each transformed anomaly value was standardized by removing the mean and 
dividing by the standard deviation of the relevant transformed dataset. Both standardized datasets are now dimensionless with a zero mean, and unit standard deviation that we increased to 10 by multiplying 10 against each standardized value. Thus, the normalized anomalies are dimensionless and have the same standard deviation $(=10)$ so that common graphical parameters can be applied to both datasets (e.g., von Frese et al., 1997a). To recover the non-normalized, original correlation-filtered anomaly value, we simply multiply the normalization factor (NF) listed for the map against the normalized value in the map. Here, the normalization factor is just the respective standard deviation of the original transformed dataset divided by 10 .

The induced total field magnetic anomaly components (Figure 2a) are displaced southwards of their crustal sources due to the low northward inclination of the inducing geomagnetic field, whereas these components in the RTP magnetic anomalies (Figure 4a) are centered over their crustal sources. Thus, by Poisson's relation, the crustal source with both density and induced magnetization contrasts exhibits spatially correlated RTP magnetic and FVD gravity anomalies (e.g., von Frese et al., 1997a; 1997b). However, the datasets in Figures $4 \mathbf{a}$ and $\mathbf{4 b}$ have a marginal $\mathrm{CC}=0.068$ that is taken commonly to indicate the lack of correlative anomaly features.

The interfering effects of superposed magnetic remanence and/or sources with only a single physical property contrast can account for this marginal CC, but numerous examples of correlated anomalies seem visually apparent in Figures $\mathbf{4 a}$ and $\mathbf{4 b}$. In general, the interpretation of any $\mathrm{CC}$ with absolute magnitude less than unity is not unique, and thus other interesting possibilities may be applicable (e.g., von Frese et al., 1997a). For example, the near-zero correlation coefficient is also consistent with essentially equal numbers of positively and negatively correlated anomaly features. Thus, to interpret the anomaly correlations more effectively, we developed wavenumber correlation filters to separate the positively and negatively correlated anomaly features in the geopotential field data (von Frese et al., 1997a; 1997b).

Specifically, we evaluated the correlation spectrum between Figures $4 \mathbf{a}$ and $\mathbf{4 b}$ given by $\mathrm{CC}(\mathrm{k})=\cos \left(\Delta \theta_{\mathrm{k}}\right)$, where $\Delta \theta_{\mathrm{k}}$ is the phase difference in the $\mathrm{k}$-th wavenumber RTP magnetic and FVD gravity components. To extract the positively correlated anomaly features, all wavenumber components for which $\mathrm{CC}(\mathrm{k})>0$ were inversely transformed. The correlation filtered outputs correlated at $\mathrm{CC}=0.554$ and passed roughly $50 \%$ of input anomaly energies. The noise $(\mathrm{N})$-to-signal $(\mathrm{S})$ ratio given by $(\mathrm{N} / \mathrm{S}) \approx \sqrt{ }[(1 /|\mathrm{CC}|)-1]$ (e.g., von Frese et al., 
1997a) suggests the noise reduction of some $76 \%$ in the positively correlated output anomaly features relative to the noise in the unfiltered input anomalies.

To enhance the perception of the stronger positive feature correlations, we standardized the correlation filtered outputs and added them together to obtain the summed local favorability indices (SLFI) in Figure 5 (e.g., von Frese et al., 1997a). Specifically, Figure 5a gives the SLFI $>+10$ to highlight the stronger anomaly peak-to-peak associations, whereas Figure 5b shows the SLFI <-10 to emphasize the stronger valley-to-valley anomaly correlations.

To extract the negatively correlated anomaly features, we inversely transformed all the wavenumber components for which $\mathrm{CC}(\mathrm{k})<-0.1$. The correlation filtered outputs correlated at $\mathrm{CC}=-0.465$ and passed roughly $45 \%$ of the input anomaly energies. The enhanced negative correlation coefficient suggests the noise reduction of about $70 \%$ in the correlation filtered anomalies relative to the unfiltered anomaly noise.

To map out the more prominent negative feature correlations, we standardized the correlation filtered outputs and subtracted them for the differenced local favorability indices (DLFI) in Figure 6. The DLFI $>+10$ emphasize the stronger RTP magnetic maximum (peak)-to-FVD gravity minimum (valley) anomaly correlations, whereas the DLFI $<-10$ give the stronger RTP magnetic valley-to-FVD gravity peak anomaly associations.

For completeness, we also investigated the correlation spectrum for non-correlative anomaly features. However, the anomaly amplitudes for the wavenumber components with ($0.3 \leq \mathrm{CC}(\mathrm{k}) \leq 0.3)$ were found to be very marginal and within the noise levels of the anomaly data sets. Thus, we did not consider these relatively minor non-correlative anomaly features further.

Instead, we focused on Figures $\mathbf{5}$ and $\mathbf{6}$ that summarize the distribution of the stronger positive and negative anomaly correlations in terms of apparent crustal magnetization and density contrasts of the Southern Tyrrhenian Sea. The lateral outlines of these apparent contrasts were determined from the zero second vertical derivatives of the correlation filtered anomalies that give first order edges of the sources in the subsurface (e.g., Blakely, 1996). In the next sections, we consider the geological implications for the anomaly correlations.

\section{Discussion}

Figures 5 and $\mathbf{6}$ map only the horizontal dimensions of apparent physical property contrasts presumed for mostly subsurface petrological, structural, and thermal variations. However, the dissimilarity in causative characteristics and range of depth of origin 
complicates assessing the geological significance of the anomaly correlations. The effects of remanence, in particular, are poorly understood for most of the study area that is underwater. Limited paleomagnetic constraints have been measured, however, for the Aeolian Archiepelago and surrounding onshore areas that show magnetite as the dominant magnetic carrier (Speranza et al., 2003; 2006; 2008; Zanella and Lanza, 1994; Zanella et al., 1999; 2001; 2004).

In general, these features as well as the seamounts and other remanently magnetized crustal sources are well-centered within their apparent RTP anomalies. Thus, the anomaly correlations at the scale of this analysis may greatly help to minimize interpretational limitations, although they cannot be uniquely related to common sources in the subsurface due to the fundamental source ambiguity of anomaly analysis. However, when combined with ancillary geological and geophysical data, they provide inter-related evidence to better understand the crustal properties and evolution of the Southern Tyrrhenian Sea.

In the next subsections, we review the apparent anomaly correlations and possible geological implications for the five sectors of the study area shown in Figure 1c. An overview of the results discussed below is given in Table 2.

\section{A) Northern Sicily Marine Sector}

The sediment covered offshore region north of Sicily to the Drepano-Elimi thrust zone is dominated mostly by correlated negative contrasts in crustal density and magnetization that include SLFI features A1, A2, A3, and A4 in Figure 5b. In addition, prominent inversely correlated positive density and negative magnetization contrasts mark the northern coastline of Sicily in the DLFI features A5 and A6 of Figure 6.

Feature A1 (Figure 5b) characterizes the Cefalù basin from the northern coastline of Sicily to the Aeolain and Ustica volcanics with negative density and magnetization contrasts. This structural depression developed from Tortonian times with various phases of compression, extension and subsidence. The E-W trending graben-like Cefalù basin includes a thick ( $23000 \mathrm{~m})$ sedimentary sequence. The long wavelength magnetic anomaly is mostly E-W oriented with minima located close to the NNW-SSE striking Tindari-Letojanni fault system and the Alicudi and Filicudi islands. The related gravity gradient effectively depicts the local structural trends, where the eastern component closely parallels the TindariLetojanni fault system and overlying Salina-Lipari-Vulcano volcanic complex (Ventura et al., 
1999). In general, feature A1 resolves correlated negative anomalies that are consistent with the effects of lower density and magnetization sediments filling the Cefalù basin.

Further westwards, feature A2 implies negative physical property contrasts for the EW elongated Ustica basin and its convergence into the NE-SW striking S. Vito Canyon. Feature A2 lies south of the Ustica Island and Mt. Anchise seamount where the gravity gradients closely mimic the pattern of these physiographic units. The Ustica basin is filled by a lower density sedimentary sequence relative to the denser volcanic rocks and Maghrebian units on the north. The overlapping effects of several possible sources increase the complexity of the magnetic anomaly field. Specifically, the negative magnetization and density contrasts of feature A2 are consistent with the effects of essentially lower density, non-magnetic sediments filling the Ustica basin, the demagnetized southern tip of the Ustica volcano, the marginally magnetized Maghrebian stacks, and the strongly magnetized Anchise and Ustica edifices to the north. The A2 magnetic and gravity anomalies also follow the terrain relief of the Ustica basin and thus probably reflect terrain effects.

Further north, feature A3 defines a roughly NW-SE elongated region of negative physical property contrasts that overlaps the basin on the northeastern slope of Ustica Island. This intraslope basin includes lateral ramps and hanging walls of the main, possibly active, NE-SW thrusts of the northern Sicily continental margin (Sulli, 2000). To the west, feature A4 overlaps a seismically determined small extensional sedimentary basin located north of the Ustica and Anchise ridge (Finetti, 2005). The negative physical property contrasts for both features A3 and A4 reflect the differences between the lower density and magnetization of the sedimentary deposits relative to surrounding higher density and magnetization volcanites.

Features A5 and A6 (Figure 6) define positive density and negative magnetization contrasts appear to be related respectively to the uplifted, roughly E-W elongated Maghrebian structural units of the northern Sicily coastline, and the NW-SE trending tectonic boundary between Maghrebian units on the west and the Peloritani mountains on the east. Here, the positive density contrast reflects the local thickening of the Maghrebian structural units, and the negative magnetic signature is consistent with the low-to-null magnetized quartzarenites and shales of the flysch nappes overlying carbonate units. The A6 gravimetric anomaly is also consistent with the terrain effect of a NW-SE bathymetric feature that extents offshore a few kilometers from the northern Sicily coastline along the strike of the nearby Tindari Letojanni fault system. 
This sector includes prominent direct correlations of positive physical property contrasts expressed by SLFI features B1, B2, B3, B4, and B5 in Figure 5a. In addition, the

413 DLFIs in Figure 6 highlight extensive inverse correlations of negative density and positive magnetization contrasts in feature B6, and positive density and negative magnetization contrasts in feature B7.

Feature B1 is west of the Marsili basin and clearly N-S elongated, but not affiliated with known seamounts in this sector of the Tyrrhenian Sea. Accordingly, feature B1 may represent an intrusion that lacks topographic expression (Marani and Gamberi, 2004).

Features B2 and B3 involve correlated magnetic and gravity signatures overlying wide elongated topographic ridges (Pepe et al., 2000). Feature B2 marks the almost ENE-WSW oriented Caesar Seamount, whereas feature B3 is centered on a WNW-ESE trending topographic ridge. In general, these features are consistent with occurrences of higher density and magnetization volcanics (Sartori, 2005) or shallow crystalline intrusions (Pepe et al., 2000) within sediments filling structural depressions. The gravimetric signatures of these features closely follow the bathymetric relief and thus may reflect significant terrain effects.

Feature B4 lies on the weak bathymetric expression of the Virgilius volcanic body in continental crust of the western Cornaglia Terrace, which represents the rifted margin of eastern Sardinia (Finetti 2005; Sartori 2005). The M-28B seismic section (Finetti and Del Ben, 2005) shows very thin Plio-Quaternary sedimentary cover and the presence of an uplifted, shallow body that can account for the positive magnetic anomaly. Thus, feature B4 probably reflects the higher density and magnetization effects of a sill-like intrusion of the sedimentary cover, and the terrain relief.

The N-S elongated B5 feature located between the western Sardinia continental slope and the Cornaglia Terrace overlies the Mt. Quirra alkaline seamount that formed at ca. $3 \mathrm{Ma}$ (Sartori, 2005). The seismic profile M-28B crossing the Sardinia margin a few kilometers north of Mt. Quirra (Finetti, 2005) reveals that the continental slope is strongly affected by listric N-S striking faults and structural depressions filled by thick sediments. Mt. Quirra lies along a curved regional master fault where mafic magmas upwelled. The N-S orientation and positive polarities of the magnetic and gravity anomalies are consistent with the effects higher density and magnetization Mt. Quirra volcanics within surrounding continental and marine sediments. 
The DLFI features B6 and B7 (Figure 6) overlie eastern Sardinia structural units and Sicilian-Maghrebian units, respectively. The boundary between these features marks the external front of the Maghrebian chain. Feature B6 probably reflects lower density, higher magnetization intrusions within the syn-rift Tortonian sediments in southeastern Sardinia, whereas feature B7 is consistent with the higher density, lower magnetization effects of Meso-Cenozoic stacks of platform carbonates and Mesozoic-Paleogene nappes of basinal carbonates (Catalano et al., 1985).

\section{C) Marsili Basin Sector}

This sector exhibits predominantly SLFI features that include the extended positive physical property contrasts marked by feature C1 (Figure 5a), and negative contrasts mapped in features C2 and C3 (Figure 5b). Feature C1 overlies the NNE-SSW elongated Marsili seamount that formed at ca. 0.2-0.1 Ma. The magnetic and gravity gradient anomalies closely follow the seamount that is composed of tholeiitic-to-calc-alkaline basalts (Marani and Trua, 2000). The positive density contrast probably reflects the relief of the Marsili volcano as well as the higher density Marsili volcanics relative to the lower density, 600-m sedimentary cover of the basin (Kastens et al., 1988). The corresponding positive magnetic signature, however, is consistent with the magnetization contrast due primarily to the relief of the volcanic edifice that was produced in the Brunhes normal chron (Savelli and Schreider, 1991). Therefore, both the magnetic and gravimetric anomaly fields the $\mathrm{C} 1$ feature probably involve significant topographic contributions from the huge Marsili volcano.

Features $\mathrm{C} 2$ and $\mathrm{C} 3$ characterize extensive regions flanking the Marsili volcano with negative physical property contrasts. These regions involve sediment covered oceanic-like crust with magnetic striping that was strongly affected by extensional tectonics which produced the ultra-fast opening of the Marsili basin (Marani and Trua, 2002).

The C2 feature includes a wide area southeast of the Marsili edifice that also overlaps the Stromboli canyon between the Calabria coastline and the Panarea and Stromboli islands (see Fig. 1c). The gravimetric signature is consistent with the negative density contrast between the lower density sedimentary cover of the Marsili basin and Stromboli canyon and the surrounding higher density volcanic seamounts and Aeolian Islands. The corresponding negative magnetization contrast from these units is enhanced by the presence of reversely magnetized seafloor strips next to the Marsili edifice (Nicolosi et al., 2006, Savelli and Schreider, 1990). 
Feature C3 involves comparable sources for the negative density and magnetization contrasts. Moreover the Marsili basin is a pelagic depression completely surrounded by high standing bathymetry. These high topographic gradients may account for the apparent terrain components in the $\mathrm{C} 1$ and $\mathrm{C} 2$ gravimetric features.

\section{D) Aeolian Islands Sector}

This sector includes extensive regions of correlated positive physical property contrasts that are highlighted in Figure 5a by SLFI features D1, D2, D3, D4, and D5. The sector also hosts prominent inverse anomaly correlations that include features D6 and D7 in Figure 6.

Feature D1 marks the active Aeolian volcanoes of Lipari, Vulcano, Panarea and Stromboli islands, feature D2 the inactive Alicudi and Filicudi island volcanoes, and feature D3 the submerged western Aeolian volcanoes between the Glauco and Eolo seamounts. The lack of lateral continuity in these three features suggests that the Aeolian volcanic blanket, which was emplaced mainly during the Brunhes normal chron, is not continuous and it is interrupted by zones where Plio-Quaternary sediments may occur. The positive magnetization and density contrasts between the volcanic blankets and the surrounding Plio-Quaternary basins (e.g., turbidites) can account for these features. Below this sedimentary cover, mostly non-magnetic and low density pre-to-syn-rift phases of acoustic basement occur (Barberi et al., 1994, Pepe et al., 2000). The gravimetric and magnetic anomalies are mostly caused by deeper sources related to the volcanic root systems, in addition to the topographic components due to the steep volcanic edifices.

Feature D4 near the Calabria coastline overlaps crystalline terrains of the Calabrian Arc. Highly magnetized intrusions of the Calabrian Arc or submerged volcanic bodies may account for this feature, but the available data cannot distinguish between the two hypotheses. Feature D4 is consistent with positive physical property contrasts of volcanic/intrusive bodies relative to the surrounding sedimentary basin sequences such as in the deep Paola and Gioia Basins.

The E-W elongated feature D5 overlaps the calc-alkaline Palinuro seamount that was emplaced at ca. 0.8-0.3 Ma during the Brunhes normal chron. It consists of E-W aligned vents and represents the northern boundary of the Marsili basin. These volcanic structures lie on the western tip of the E-W striking Palinuro fault, which to the north delimits the active, roll backing slab below the Calabrian Arc (Chiarabba et al., 2008). Feature D5 highlights the 
positive physical property contrasts due to the higher magnetization and density Palinuro volcanics relative to the surrounding sediments. The apparent negative magnetization contrast of the sediments is enhanced by the underlying reversely magnetized strips of the Marsili oceanic basin. The Palinuro D5 gravimetric and magnetic anomalies appear to result from the combined effects of the volcanic roots and terrain components like was suggested for the D2 and D3 features.

The inversely correlated features D6 and D7 are located along the western margin of the Paola basin. The geologic interpretation of feature D6 is enigmatic because it marks a relatively higher magnetization, lower density region that includes outcropping acoustic basement of the Tyrrhenian Sea. However, feature D7 is consistent with the higher density, lower magnetization effects noted previously for features A5 and A6 along the northern coast of Sicily. A seismic line crossing the Paola basin (Finetti and Del Ben, 2005) suggests that the NNW-SSE elongated feature D7 overlaps the western structural boundary of the Paola basin which is tectonically controlled by NNW-SSE faulting (Fabbri et al., 1981). This boundary consists of a local, fault controlled, uplifted block of the crystalline rocks of the Calabrian Arc covered by a thin sequence of sediments. Thus, the shallower depth of the higher density, low-magnetization crystalline Calabrian-Peloritan basement rocks may account for the correlative positive gravity and negative magnetic anomaly signatures.

\section{E) Drepano-Elimi Sector}

This sector includes directly correlated SLFI features E1, E2, and E3 in Figure 5a that mark prominent regions of positive physical property contrasts. In addition, Figure 6 reveals inversely correlated DLFI features E5, E7, E9, and E11 that highlight areas of negative density and positive magnetization contrasts, whereas the features E6, E8, and E10 reflect extensive regions of positive density and negative magnetization contrasts.

Features E1 and E2 lie on the $200 \mathrm{~km}$, WSW-ENE elongated ridge that is the topographic expression of the Drepano-Elimi shear-thrust zone. Feature E1 includes Ustica Island, which formed between 0.73 and $0.13 \mathrm{Ma}$, and the Elimi chain and Anchise volcanic seamount that formed at ca. 5.3-3.5 Ma. Feature E2 is associated with the Aceste seamount

540 that formed at ca. $5 \mathrm{Ma}$ and two other seamounts of unknown ages. The gravimetric 541 signatures for both features are consistent with the terrain effects of more dense volcanic 542 seamounts relative to the surrounding, lower density seawater and sediments, as well as the 543 topographically depressed Maghrebian tectonic stacks. 
The magnetic maxima of feature E1 enclose the northern sectors of the Anchise and Ustica volcanoes, whereas the minima (e.g., feature A2 in Figure 5b) are concentrated in the southern sectors. For the Anchise seamount, which formed in a wide time span that involved the Gilbert and Gauss normal chrons, the minima overlie two small cones located on the northern flank of the main edifice. Therefore, the positive magnetic signature probably reflects the development of the northern Anchise sector during a normal chron. For the Ustica volcanic complex, the magnetic signature is subdivided into intense minima on the southeastern side and maxima on the northern half (Figure 4a). In the absence of evidence of widespread thermal demagnetization, we posit that the southeastern side may have been emplaced during a reversed polarity chron before the Matuyama chron when the outcropping subaerial basalts were extruded (Savelli, 2001, 2002 and references therein).

Feature E2 is related to a regional magnetic maximum located a few kilometers north of the Mt. Aceste seamount. The seamount was emplaced during the Brunhes C3n-3 normal chron (Marani and Gamberi, 2004) and its northern flank is affected by an amphitheater-like depression possibly reflecting a sector collapse of the northern flank of the Aceste edifice. Accordingly, the positive magnetic anomaly may involve the effects of the seamount's plumbing system denudated by the collapse of the northern flank. This interpretation is analogous to explanation for the magnetic anomalies observed on the flank collapses at the El Hierro volcano of the Canary Islands (Blanco-Montenegro et al., 2008). The positive correlation of magnetic and gravity maxima of the Aceste seamount is consistent with higher magnetization and density alkaline volcanics displacing the surrounding Maghrebian units.

Feature E3 at the northwestern corner of Sicily includes the Cofano Gulf and part of the Sicily continental margin. Here, the carbonatic units of the Maghrebian chain outcrop in a sequence of uplifted stacks and structural basins that are bounded on the north by the Drepano-Elimi thrust-shear zone. The gravimetric and magnetic signatures overlap the uplifted NNW-SSE trending stacks. The anomaly correlation is consistent with the positive density contrast that the higher density pre-Tortonian carbonates exhibit relative to the less dense terrigenous sediments filling the structural depressions. The positive magnetization contrast of the E3 feature may reflect the occurrences of higher magnetization pre-Tortonian carbonates in effectively non-magnetic basin sediments of the southern Tyrrhenian Sea. However, this hypothesis is very equivocal because paleomagnetic data on these rocks are lacking.

The roughly E-W elongated, lower magnetization, higher density feature E4 located west of the Anchise Seamount (Figure 6) overlaps uplifted acoustic basement (Finetti, 2005) 
that consists of essentially non-magnetic rocks (Barberi et al., 1994, Pepe et al., 2000). This feature together with the E-W elongated Ustica Island and Anchise ridge marks the southern margin of the Tyrrhenian Sea basin.

The NW-SE striking, sub-parallel features E5, E6, E7, E8, E9 and E10 describe an alternating sequence of inverse anomaly correlations off the western margin of Sicily. In all these cases, terrain effect components may be considered. The lower density features E5, E7, and E9 and E11 overlap sediment filled, NNW-SSE elongated basins of the Maghrebian chain, whereas the higher density features E6, E8, and E10 mark the intervening structural highs of the chain. Features E7 and E11 are characterized by pronounced positive magnetic anomalies, whereas features E5 and E9 involve more marginal magnetic maxima. Features E6, E8 and E10 reflect the physical property contrasts between the higher density and weakly magnetized flysch units of the Maghrebian structural highs and the lower density and magnetization sediments of the intra-chain basins. These basin sediments are especially well marked by features E5 and E9, but the magnetic properties of the sediments are still poorly known.

Features E7 and E11 mark correlated negative gravity and positive magnetic anomalies that overlap topographic depressions. Hence, these features may reflect subvolcanic bodies within structural lows. Indeed, the positive magnetic anomaly of feature E11 may reflect the subsurface plumbing of the Aceste volcanic system such as was previously ascribed to feature E2.

\section{Summary and Conclusions}

The complex magnetic and gravity anomaly patterns of the South Tyrrhenian Sea show numerous feature correlations to help constrain geological analysis and modelling of the magnetization and density properties of the crust. Wavenumber correlation filtering of the RTP magnetic and FVD free-air gravity anomalies established insights on the region's correlative magnetic and gravimetric geology. The approach used notch filters based on the correlation spectrum between the two data sets as determined by the cosine of the phase difference between the common wavenumber components. The spectral correlation filters in this study separated positively from negatively correlated anomaly features.

Figures $\mathbf{5 a}$ and $\mathbf{5 b}$ give the summed normalized filter outputs where positively correlated anomaly features were extracted to highlight crustal regions of correlative positive and negative magnetization and density contrasts, respectively. Figure 6, on the other hand, 
612 shows the differenced normalized filtered outputs where negatively correlated anomaly

613 features were estimated that identify crustal regions with correlative inverse magnetization

614 and density contrasts. As summarized in Tables $\mathbf{1}$ and 2, upper crustal sources can be related

615 to most of the anomaly correlations of the Southern Tyrrhenian Sea.

616 The positive anomaly correlations are mainly due to volcanic structures and 617 secondarily to intrusive bodies and pre-Tortonian units such as the carbonates of the 618 Maghrebian chain and the basement rocks of the Sardinian eastern margin. The volcanites, 619 which mainly consist of poorly evolved products emplaced in the last 5 Ma over several 620 magnetic polarity chrons, have calc-alkaline, shoshonitic, alkaline and MORB-type affinities. 621 However, the majority of the Southern Tyrrhenian volcanics were emplaced in the last $1 \mathrm{Ma}$ 622 during the Brunhes normal Chron. Therefore, these volcanic rocks represent the main source 623 of the correlative positive magnetic and gravity anomalies. The correlative negative 624 anomalies, on the other hand, principally reflect the presence of sediments filling the peri625 Tyrrhenian structural basins due to Pliocene extensional tectonics, and the intra-slope depressions related to the post-Pliocene and still-active compression tectonics of the northern 627 Sicily.

628 Prominent inverse anomaly correlations mainly reflect crustal features around the 629 southern margin of the Tyrrhenian Sea. These features include the pelagic-to-terrigenous and 630 flysch-type nappes of the Sicilian-Maghrebian chain, the sediments filling depressions of the chain, the syn-rift sediments of southeastern Sardinia, and the sediment-filled basins.

The correlation analysis suggests that crustal tectonics strongly influenced the magnetic and gravimetric anomaly fields (Figures 3 and 4) with the anomalies lying mainly on or in close proximity of the main faults and structural units (e.g., the Drepano-Elimi thrustshear zone, the Tindari-Letojanni fault system, the Marsili oceanic ridge, the faults bounding the main sedimentary basins). The SLFI features highlight this correspondence because most of the volcanic activity developed along these structural discontinuities.

The magnetic anomaly field (Figure 4a) is mainly characterized by widespread long wavelength negative anomalies concentrated in the central and eastern sectors of the Southern Tyrrhenian Sea. The western and southern sectors feature long wavelength positive anomalies. Medium-to-short wavelength positive anomalies mark the seamounts, bathymetric ridges and the Aeolian volcanics. The regional negative pattern corresponds to lithotypes characterized by low-to-null magnetization pre-Tortonian continental basement rock around

644 the Vavilov and Marsili Basins, and reversely magnetized oceanic crust such as in the Marsili Basin (Nicolosi et al., 2006, Savelli and Schreider, 1990). 
The gravimetric anomaly field (Figures $\mathbf{3 b}$ and $\mathbf{4 b}$ ) exhibits a complex pattern of widespread wavelengths and intensities. Prominent gravity anomalies mainly reflect occurrences of tectonized stacks of uplifted crustal rocks, E-W elongated structural depressions filled by thick sedimentary sequences, and volcanic islands and seamounts. These anomalies are principally due to the terrain effects, as well as the density contrasts with the surrounding lithotypes. Both positive and negative gravity anomalies cluster along the main regional tectonic structures, especially in the western and northwestern offshore regions of Sicily where thrusts and normal faults occur and follow E-W, WSW-ENE and NW-SE strike trends.

In summary, the wavenumber correlation analysis facilitates the geologic interpretation of the large and complex data sets represented by the geopotential anomaly field observations of the Southern Tyrrhenian Sea. The results provide the basis for expanding our insight on the general lithologies and tectonic evolution of the crust where outcrop data are largely lacking. They also enhance our regional perspective of the petrological, structural, and thermal properties of the Southern Tyrrhenian Sea. However, care must be taken in their use because these results are not unique and subject to errors in the data and assumptions by which they were obtained.

Acknowledgements This study was funded by the INGV. We thank Fabio Caratori Tontini

Braidenberg for constructive comments and suggestions that improved the manuscript.

\section{References}

669

670

671

672

673
Argnani, A., and C. Savelli 2001. Magmatic signature of episodic back-arc rifting in the southern Tyrrhenian Sea. In P. A. Ziegler (Ed), Peri-Tethyan Rift/Wrench Basins and Passive Margins, Peri-Tethys, Mememory Museum of Natural History, 186, pp. 735 754.

Barberi, F., Gandino, A., Gioncada, A., La Torre, P., Sbrana, A., and Zenucchini, C. 1994. The deep structure of the Eolian arc Filicudi-Panarea-Vulcano sector in light of gravity, magnetic and volcanological data. Journal of Volcanology and Geothermal Research 61, 189-206.

Barone, A., Fabbri, A., Rossi, S., Sartori, R., 1982. Geological structure and evolution of the marine areas adjacent to the Calabrian arc. Earth Evolution Sciences 3, 207- 221.

Bartole, R. 1995. The North Tyrrhenian-northern Apennines post-collisional system: Constraints for a geodynamic model. Terra Nova 7, 7-30.

Blakely, R.J., 1996. Potential theory in gravity and magnetic applications. Cambridge University Press, pp. 441. 
Blanco-Montenegro, I., Nicolosi, I., Pignatelli, A., Chiappini, M., 2008 Magnetic imaging of the feeding system of oceanic volcanic islands: El Hierro Canary Islands. Geophysical Journal International 173, 339-350.

Blanco-Montenegro I., De Ritis R., and Chiappini, M. 2007 Imaging and modelling the subsurface structure of volcanic calderas with high-resolution aeromagnetic data at Vulcano (Aeolian Islands, Italy), Bull. Volcanol.69 (6), 643-659, doi: 10.1007/s00445006-0100-7.

Caratori, F., Tontini, F. Cocchi, L. Carmisciano, C., 2008. Potential-field inversion for a layer with uneven thickness: The Tyrrhenian Sea density model. Physics of the Earth Physics of the Earth and Planetary Interiors 166, 105-11.

Carminati, E., Wortel, M.J.R., Spakman, W., Sabadini, R., 1998. The role of slab detachment processes in the opening of the western-central Mediterranean basins: some geological and geophysical evidence, Earth Planetary Science Letters 160, 651- 665.

Catalano, R., D’Argenio, B., Montanari, L., Morlotti, E., Torelli, L., 1985. Marine geology of the NW Sicily offshore Sardinia Channel and its relationships with mainland structures. Bollettino Società Geologica Italiana 104, 207-215.

Catalano, R., Doglioni, C., Merlini, S., Sulli, A., 2002. The subduction of the Ionian crust and the outer Calabrian Accretionary Wedge. EAGE Workshop 'Geodynamics of the Mediterranean and Impact on Hydrocarbon Exploration' May, 27-30, EAGE, Florence, Italy.

Cella, F., Fedi, M., Florio, G., Rapolla, A., 1998. Gravity modeling of the litho-asthenosphere system in the Central Mediterranean. Tectonophysics 287, 117-138.

Chiappini, M., Meloni, A., Boschi, E., Faggioni, O., Beverini, N., Carmisciano, C., Marson, I., 2000. On shore-offshore integrated shaded relief magnetic anomaly map at sea level of Italy and surrounding areas. Annals of Geophysics 43, 983-989.

Chiarabba, C., De Gori, P., Speranza, F. 2008. The southern Tyrrhenian subduction zone: Deep geometry, magmatism and Plio-Pleistocene evolution. Earth and Planetary Science Letters 268, 408-423.

Cimini, G.B., 1999. P-wave deep velocity structure of the Southern Tyrrhenian subduction zone from nonlinear teleseismic traveltime tomography. Geophysical Research Letters 26, 3709-3712.

Compagnoni, R., Morlotti, E., Torelli, L., 1989. Crystalline and sedimentary rocks from the scarps of the Sicily-Sardinia trough and Cornaglia Terrace Southwestern Tyrrhenian Sea: paleogeographic and geodynamic implications. Chemical Geology 77, 375-398.

De Astis, G., Ventura, G., Vilardo, G., 2003. Geodynamic significance of the Aeolian volcanism Southern Tyrrhenian Sea, Italy in light of structural, seismological and geochemical data. Tectonics 22, 1040. doi: 10.1029/2003TC001506

Del Ben, A., Guarnieri, P., 2000. Neogene transgression in the Cefalu' Basin southern Tyrrhenian: comparison between land and marine data. Memorie Societa' Geological Italiana 55, 27-33.

Doglioni, C., Gueguen, E., Harabaglia, P., Mongelli F., 1999. On the origin of W-directed subduction zones and applications to the western Mediterranean. Geological Society of America, Special Paper 156, 541-561.

Fabbri, A., Gallignani, P., Zitellini, N., 1981. Geologic evolution of the Peri-Tyrrhenian sedimentary basins of Mediterranean margins. In: Wezel, F.C. (Ed) Sedimentary Basins of Mediterranean Margins. Tecnoprint, Bologna, Italy, pp. 101-126.

Faccenna, C., Becker, T.W., Lucente, F.P., Jolivet, L. Rossetti F.; 2001:History of subduction and back-arc extension in the Central Mediterranean. Geophysical Journal International $145,809-820$. 
Faccenna, C., Piromallo, C., Crespo-Blanc, A., Jolivet, L., Rossetti, F., 2003. Lateral slab deformation and the origin of the western Mediterranean arcs. Tectonics 23, DOI:10.1029/2002TC001488.

Faggioni, O., Pinna, E., Savelli, C. Schreider, A.A., 1995. Geomagnetism and age study of Tyrrhenian seamounts. Geophysical Journal International 123, 915-930.

Finetti, I. (Ed) 2005. Deep Seismic Exploration of the Central Mediterranean and Italy. Elsevier, Amsterdam, 794 pp.

Finetti, I., Del Ben, A., 2005. Ionian Tethys Lithosphere Roll-Back Sinking and Back-Arc Tyrrhenian Opening from New CROP Seismic Data. In Finetti I. (Ed) CROP-Crustal Seismic Exploration of the Mediterranean Region. Amsterdam, Elsevier, pp. 483-504.

Giunta, G., Bellomo, D., Carnemolla, S., Pisano, A., Profeta, R., Runfola, P., 1992. La linea di Taormina: residuo epidermico di una paleostruttura crostale del fronte cinematico maghrebide?. Atti Convegno GNGTS Roma, 1197-1213.

Goes, S., Giardini, D., Jenny, S., Hollenstein, C., Kahle, H-G., Geiger, A., 2006. A recent tectonic reorganization in the South-Central Mediterranean. Earth and Planetary Science Letters 225, 335-345.

Gvirtzman, Z., Nur, A., 1999. The formation of Mount Etna as the consequence of slab rollback. Nature 401, 782-785.

Gvirtzman, Z., Nur, A., 2001. Residual topography, lithospheric structure and sunken slabs in the Central Mediterranean. Earth and Planetary Science Letters 187, 117-130.

Hollenstein, C., Kahle, H.-G., Geiger, A., Jenny, S., Goes, S., Giardini, D., 2003. New GPS constraints on the Africa-Eurasia Plate Boundary Zone in Southern Italy. Geophysical Research Letters 30(18), 1935, doi:10.1029/2003GL017554.

Kastens, K., Mascle, J., Auroux, C.,1988. ODP Leg 107 Scientific Party. 1988 - ODP Leg 107 in the Tyrrhenian sea: Insights into passive margin and back-arc basin evolution. Geological Society of America Bulletin 100, 1140-1156.

Malinverno, A., Ryan, W.B.F., 1986. Extension in the Tyrrhenian Sea and shortening in the Apennines as result of arc migration driven by sinking of the lithosphere. Tectonics 5, 227-245.

Marani, M. P., Gamberi, F., 2004. Structural framework of the Tyrrhenian Sea unveiled by seafloor morphology. In: Marani, F. Gamberi, E. Bonatti (Eds), From seafloor to deep mantle: architecture of the Thyrrhenian backarc basin. Memorie descrittive della Carta Geologica d'Italia, LXIV, APAT, Servizio Geologico d'Italia, 2004.

Marani, M.P., Trua, T., 2002. Thermal constriction and slab tearing at the origin of a superinflated spreading ridge: Marsili volcano Tyrrhenian Sea. Journal of Geophysical Research 107(B9), 2188, doi:10.1029/2001JB000285.

Marotta, A. M., Barzaghi, R., Borghi, A., Spelta, E., 2007. Gravity constraints on the dynamics of the crust-mantle system during Calabrian subduction. Geophysical Journal International 171, 977-985.

Mascle, J., Kastens, K., Auroux, C., Party, L.S.D., 1988. A land-locked back-arc basin: preliminary results from ODP Leg 107 in the Tyrrhenian Sea. Tectonophysics 146, 149-162.

Montone, P., Amato A. and Pondrelli, S., 1999. Stress map of Italy. Journal of Geophysical Research 104, 25595-25610.

Montuori, C., Cimini, G.B., Favali, P. 2007. Teleseismic tomography of the southern Tyrrhenian subduction zone: New results from seafloor and land recordings. Journal of Geophysical Research 112, B03311, doi:10.1029/2005JB004114.

Nicolosi, I., Speranza, F., Chiappini, M., 2006. Ultrafast oceanic spreading of the Marsili basin, southern Tyrrhenian Sea: Evidence from magnetic anomaly analysis. Geology, 349, 717-720. 
Nigro, F., Sulli, A., 1995. Plio-Pleistocene extensional tectonics in the western Peloritani area and its offshore northeastern Sicily,. Tectonophysics 252, 295-305.

Patacca, E., Scandone, P., 1989. Post-Tortonian mountain building in the Apennines. The role of the passive sinking of a relic lithospheric slab. Atti Convegno Lincei 80, 157-176.

Patacca, E., Sartori, R., Scandone, P., 1993. Tyrrhenian basin and Apennines. Kinematic evolution and related dynamic constraints. NATO ASI Series C 402, 161-171.

Pepe F., Sulli, A., Bertotti, G., Catalano, R., 2005. Structural highs formation and their relationship to sedimentary basins in the north Sicily continental margin southern Tyrrhenian Sea: Implication for the Drepano Thrust Front. Tectonophysics 409, 1-18.

Pepe, A., Sulli, M., Agate, D., Di Maio, A., Kok, C., Lo Iacono, Catalano, R., 2003. PlioPleistocene geological evolution of the northern Sicily continental margin southern Tyrrhenian Sea: new insights from high-resolution, multi-electrode sparker profiles. Geo-Marine Letters 23, 53-63.

Pepe, F., Bertotti, G., Cella, F., Marsella, E., 2000. Rifted margin formation in the south Tyrrhenian Sea: A high-resolution seismic profile across the north Sicily passive continental margin. Tectonics 19, 241-257

Piromallo, C., Morelli, A., 1997. Imaging the Mediterranean upper mantle by P-wave travel time tomography. Annali di Geofisica, XL4, 963-979.

Rosenbaum, Gand Lister, G. S., 2004. Neogene and Quaternary rollback evolution of the Tyrrhenian Sea, the Apennines and the Sicilian Maghrebides. Tectonics, 23, TC1013, doi:10.1029/2003TC001518.

Sandwell, D. T., W. H. F. Smith, Marine gravity anomaly from Geosat and ERS 1 satellite altimetry, Journal of Geophysical Research, v. 102 , No. B5, p. 10039-10054, 1997.

Sartori, R., 2005. Bedrock geology of the Tyrrhenian Sea. In: Finetti I. (Ed). Deep Seismic Exploration of the Central Mediterranean and Italy. Elsevier, Amsterdam, 794 pp.

Sartori, R., Carrara, G., Torelli, L., Zitellini, N., 2001. Neogene evolution of the southwestern Tyrrhenian Sea Sardinia Basin and western bathyal plain. Marine Geology 175, 47 - 66.

Savelli, C., Schreider, A.A., 1991. The opening processes in the deep Tyrrhenian basins of the Marsili and Vavilov, as deduced from magnetic and chronological evidence of their igneous crust. Tectonophysics 190, 119-131.

Savelli, C., 2001. Two-stage progression of volcanism $8-0$ Ma in the central Mediterranean southern Italy. Journal of Geodynamics 31, 393-410.

Savelli, C., 2002. Time-space distribution of magmatic activity in the western Mediterranean and peripheral orogens during the past $30 \mathrm{Ma}$ a stimulus to geodynamic considerations. Journal of Geodynamics 34, 99- 126.

Serri, G.. 1990. Neogene-Quaternary magmatism of the Tyrrhenian region: characterization of the magma sources and geodynamic implications. Memorie Societa' Geologica Italiana 41, 219-242.

Spakman, W., van der Lee, S., van der Hilst, R., 1993. Travel-time tomography of the European-Mediterranean mantle down to $1400 \mathrm{~km}$. Physics of the Earth and Planetary Interiors 791-2, 3-74.

Speranza, F., Pompilio, M., D’Ajello Caracciolo, F., and Sagnotti, L., 2008 Holocene eruptive history of the Stromboli volcano: Constraints from paleomagnetic dating. Journal of Geophysical Research VOL. 113, B09101, doi:10.1029/2007JB005139.

Speranza, F., S. Branca, M. Coltelli, F. D’Ajello Caracciolo, and Vigliotti, L., 2006, How accurate is "paleomagnetic dating"? New evidence from historical lavas from Mount Etna, Journal of Geophysical Research, 111, B12S33, doi:10.1029/2006JB004496.

Speranza, F., Maniscalco, R., Grasso, M., 2003. Pattern of orogenic rotations in centraleastern Sicily: implications for the timing of spreading in the Tyrrhenian Sea. Journal Geological Society of London 160, 183-195. 
833

834

835

836

837

838

839

840

841

842

843

844

845

846

847

848

849

850

851

852

853

854

855

856

857

858

859

860

861

862

863

864

865

866

867

868

869

870

871

872

873

874

875

876

877

Sulli, A., 2000. Structural framework and crustal characters of the Sardinia Channel alpidic transect in the central Mediterranean. Tectonophysics 324, 321-336

Torelli, F., Cornini, S., Brancolini, G., Zitellini, N., 1991. The Sardinia Channel Central Mediterranean: a structural analysis of a submarine orogenic chain. Studi Geologici Camerti, Special Issue 1990, 35- 36.

Ventura, G., Vilardo, G., Milano, G., Pino, N.A., 1999. Relationship among crustal structure, volcanism and strike-slip tectonics in the Lipari-Vulcano Volcanic Complex Aeolian Islands, Southern Tyrrhenian Sea, Italy. Physics of the Earth and Planetary Interiors $116,31-52$.

von Frese R.R.B., Hinze, W.J., Braile, L.W., 1982. Regional north-american gravity and magnetic anomaly correlations. Geophysical Journal of the Royal Astronomical Society 69, 745-761.

von Frese R.R.B., Jones, M.B, Kim, J.W., 1997a. Spectral correlation of magnetic and gravity anomalies of Ohio. Geophysics 62, 365-380.

von Frese R.R.B, Jones, M.B., Kim, J.W., 1997b. Analysis of anomaly correlations, Geophysics 62, 342-350.

Westaway, R., 1993. Quaternary uplift of Southern Italy. Journal of Geophysical Research 98, 21741-21772.

Zanella, E, Lanza, R., 1994. Remanent and induced magnetization in the volcanites of Lipari and Vulcano (Aeolian Islands). Ann. Geophys 37:1149-1156

Zanella, E., De Astis, G., Dellino, P., Lanza, R, La Volpe, L., 1999. Magnetic fabric and remanent magnetization of pyroclastic surge deposits from Vulcano (Aeolian Islands, Italy). J Volcanol Geotherm Res 93:217-236

Zanella, E., De Astis, G., Lanza, R., 2001. Palaeomagnetism of welded, pyroclastic-fall scoriae at Vulcano, Aeolian Archipelago. J Volcanol Geotherm Res 107:71-86 


\section{Figure 1}

(a) Geodynamic setting of Italy and Southern Tyrrhenian Sea (modified from De Astis et al., 2003). (b) Structural sketch map of the Southern Tyrrhenian Sea (data from Savelli, 2001; Sartori, 2001; Rosenbaum and Liste, 2004; Pepe et al., 2005). Dotted lines give the depth (in $\mathrm{km}$ ) of the earthquakes in the Southern Tyrrhenian Sea. (c) Shaded relief map of the Southern Tyrrhenian Sea. The main faults, volcanoes and seamounts (triangles) are from Savelli (2001), Sartori (2001), and De Astis et al. (2003). The geographic names of the localities reported in the text are also shown. The sectors considered by this study include: (A) the northern Sicily and southern Calabria domain, (B) the southwestern Tyrrhenian Sea sector including the Sardinia margin, (C) the Marsili Basin sector, (D) the Aeolian Islands and seamounts, and (E) the Drepano-Elimi thrust zone and eastern Sardinia margin.

\section{Figure 2}

(a) Total field magnetic anomalies of the Southern Tyrrhenian Sea and Northern Sicily upward continued to $3 \mathrm{~km}$ above sea level. (b) Free-air gravity anomalies of the Southern Tyrrhenian Sea and Northern Sicily at $3 \mathrm{~km}$ altitude. Statistics listed for these and subsequent maps include the amplitude range (AR) of (min, max)-values, amplitude mean (AM), amplitude standard deviation (ASD), amplitude units (AU), grid interval (GI), and map altitude (Z). The alphanumeric labels on the prominent data features are given in Table 2.

\section{Figure 3}

902 Modeled gravity and magnetic effects of a seamount. (a) Crustal thickness model of the 903 seamount with bottom at $-2000 \mathrm{~m}$ below sea level and located a few kilometers north of the northern coast of Sicily. (b) Induced total magnetic field effects of the seamount modeled with induction intensity $\mathrm{J} 1=2.8 \mathrm{~A} / \mathrm{m}$, inclination $\mathrm{I} 1=54^{\circ} \mathrm{N}$, and declination $\mathrm{D} 1=2^{\circ} \mathrm{E}$. (c)

906 Induced RTP magnetic effects of the seamount modeled with $\mathrm{J} 1, \mathrm{I} 2=90^{\circ}$, and D2 $=0^{\circ}$. These results are the total field effects in Map b reduced-to-the-pole. (d) Gravity effects of the seamount modelled for the density contrast $\Delta \sigma=3 \mathrm{~kg} / \mathrm{m}^{2}$. (e) FVD of the gravity effects in

909 Map d. (f) Total magnetic field effects of the seamount modelled induction parameters J1, I1, 910 and D2 plus a deep volcanic body with induced $\mathrm{J} 2=0.70 \mathrm{~A} / \mathrm{m}, \mathrm{I} 1$, and D1, and remanent $\mathrm{J} 3$ $911=1.6 \mathrm{~A} / \mathrm{m}, \mathrm{I} 3=-54^{\circ} \mathrm{S}$, and D3 $=-2^{\circ} \mathrm{W}$. (g) RTP magnetic effects of the seamount model in 
912 Map f computed with I2 and D2. The red contour in Map a highlights the $-1300 \mathrm{~m}$

913 bathymetric level that is represented by white contours in the rest of the maps. Correlation

914 coefficients (CC) between the maps are also listed.

915

\section{Figure 4}

917 (a) Normalized reduced-to-pole (RTP) magnetic anomalies. (b) Normalized first vertical 918 derivative (FVD) free-air gravity anomalies. Normalization factors (NF) are listed for each 919 map that may be multiplied against the normalized data to convert them to the original 920 anomaly values. The alphanumeric labels on the prominent data features are given in Table 921 2.

922

\section{Figure 5}

924 Summed local favorability indices (SLFI) for the normalized outputs from wavenumber 925 correlation filtering the data sets of Figure 3 for $\mathrm{CC}(\mathrm{k})>0$. (a) The stronger peak-to-peak 926 correlations characterized by SLFI $>+10$ (red shaded) broadly delineate regions of relatively 927 positive density and magnetization contrasts $\Delta \sigma(+)$ and $\Delta \mathrm{m}(+)$, respectively. (b) The stronger 928 trough-to-trough correlations characterized by SLFI < -10 (blue shaded) outline relatively 929 negative density and magnetization contrasts $\Delta \sigma(-)$ and $\Delta \mathrm{m}(-)$, respectively. The 930 alphanumeric labels on the prominent data features are given in Table 2.

\section{Figure 6}

933 Differenced local favorability indices (DLFI) for the normalized outputs from wavenumber 934 correlation filtering the data sets of Figure 3 for $\mathrm{CC}(\mathrm{k})<-0.1$. The positive DLFIs (yellow 935 shaded) map out the stronger gravity peak-to-magnetic trough correlations for DLFI $>+10$ 936 that roughly delineate regions of relatively positive density and negative magnetization 937 contrasts $\Delta \sigma(+)$ and $\Delta \mathrm{m}(-)$, respectively. The negative DLFIs (green shaded) highlight the 938 stronger gravity trough-to-magnetic peak correlations for DLFI $<-10$ that broadly outline 939 relatively negative density and positive magnetization contrasts $\Delta \sigma(-)$ and $\Delta \mathrm{m}(+)$, 940 respectively. The alphanumeric labels on the prominent data features are given in Table 2. 


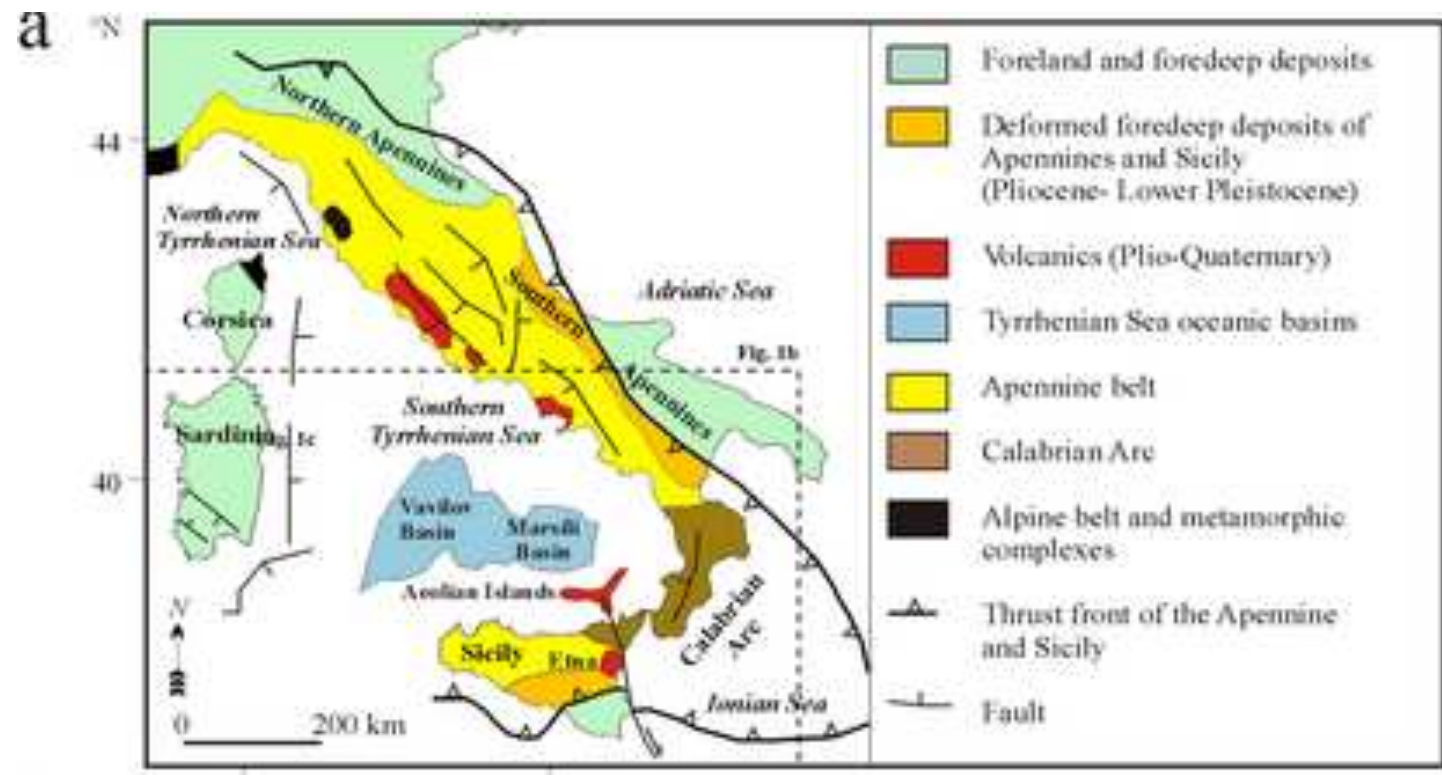

b

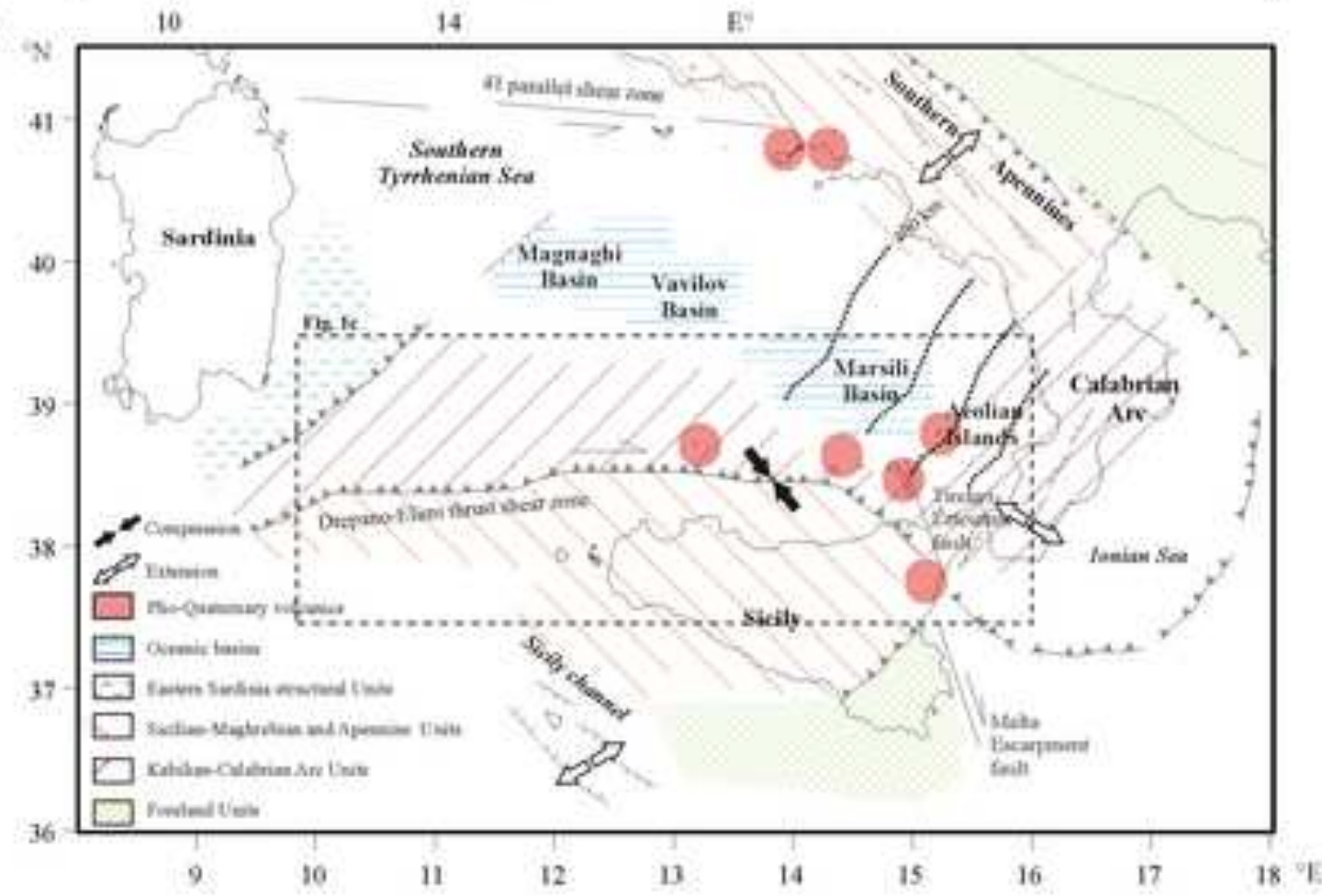

c

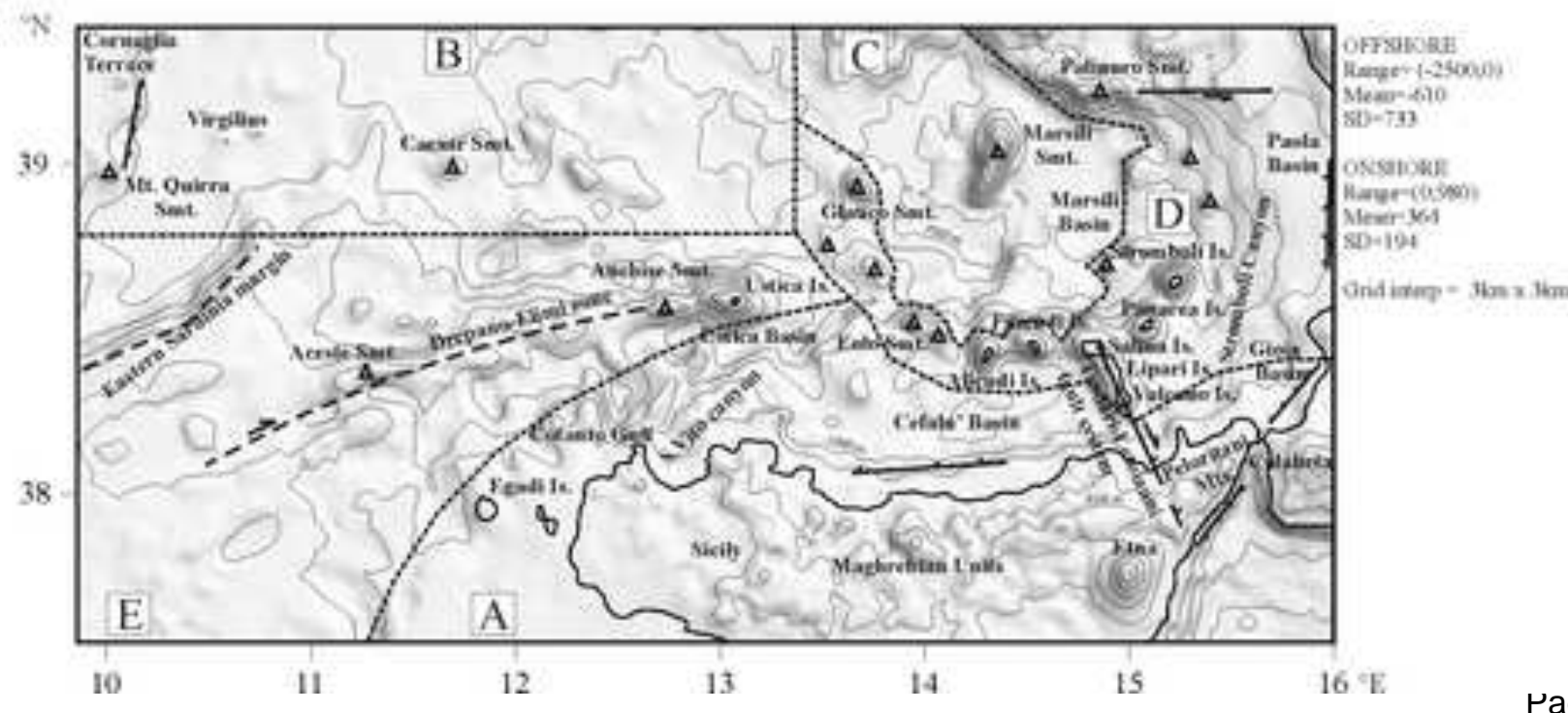




\section{Figure(s)}

ACCEPTED MANUSCRIPT

Click here to download high resolution image
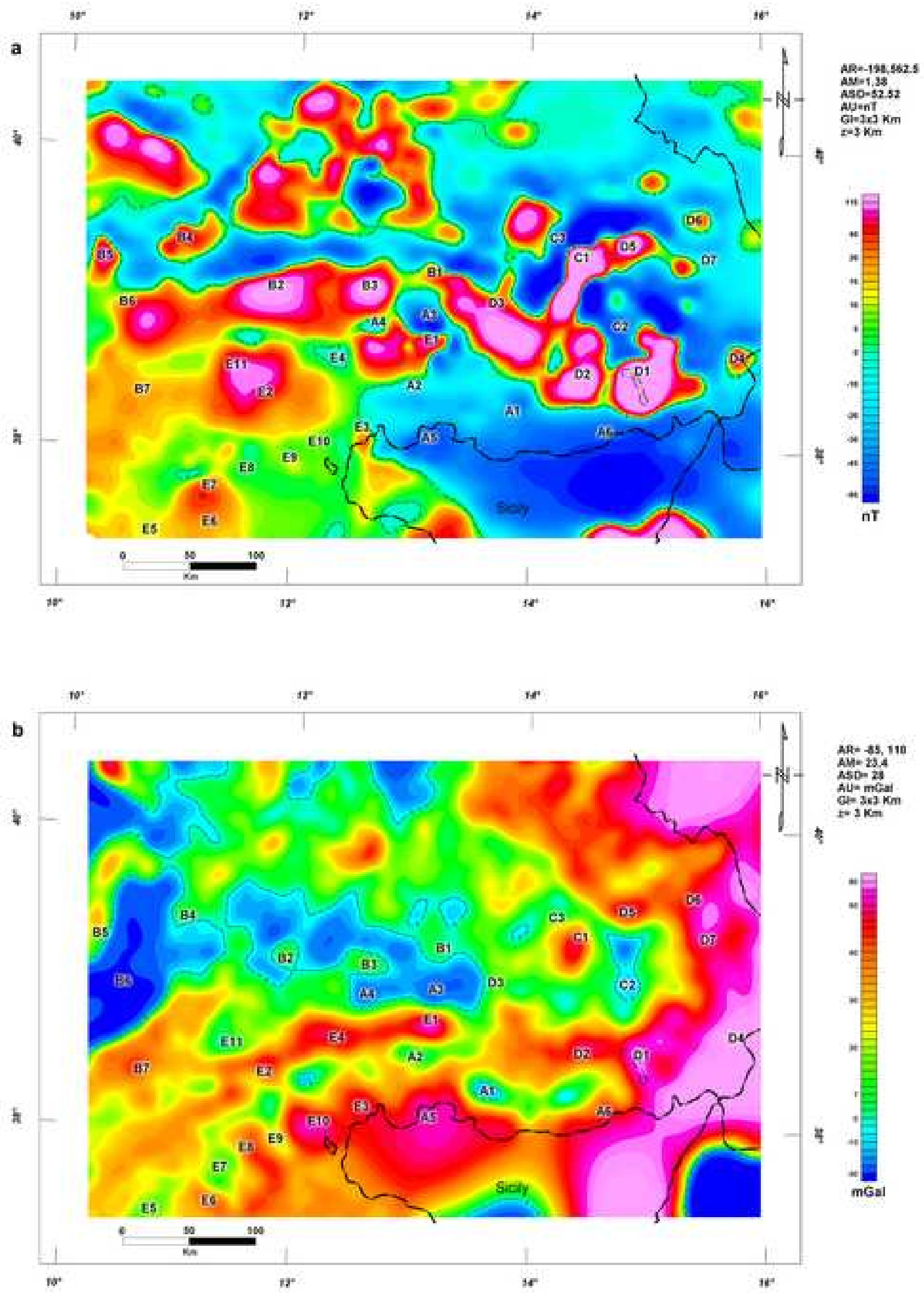


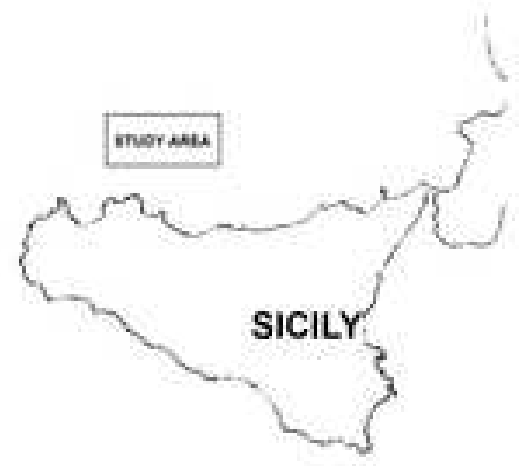

a
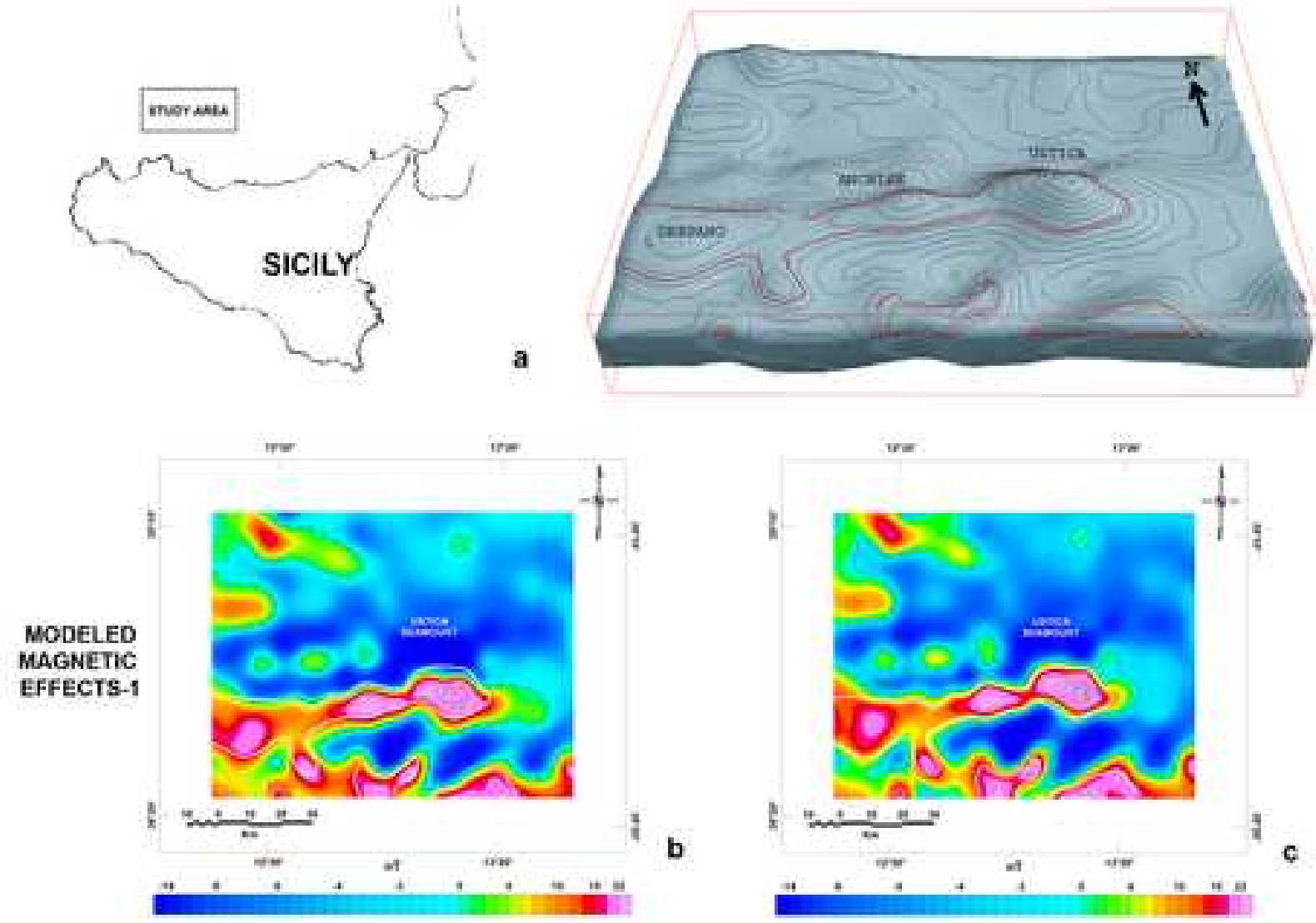

b

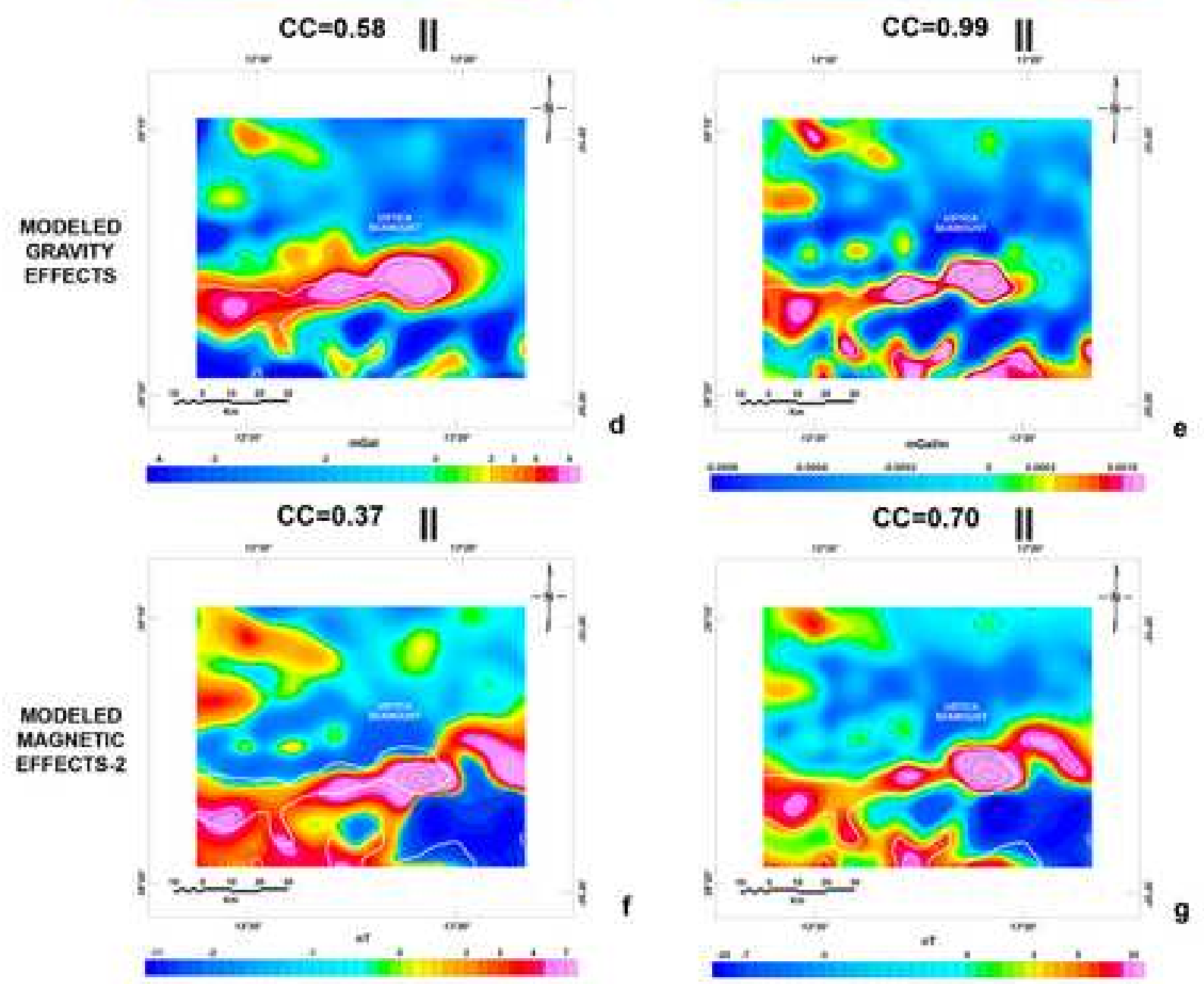



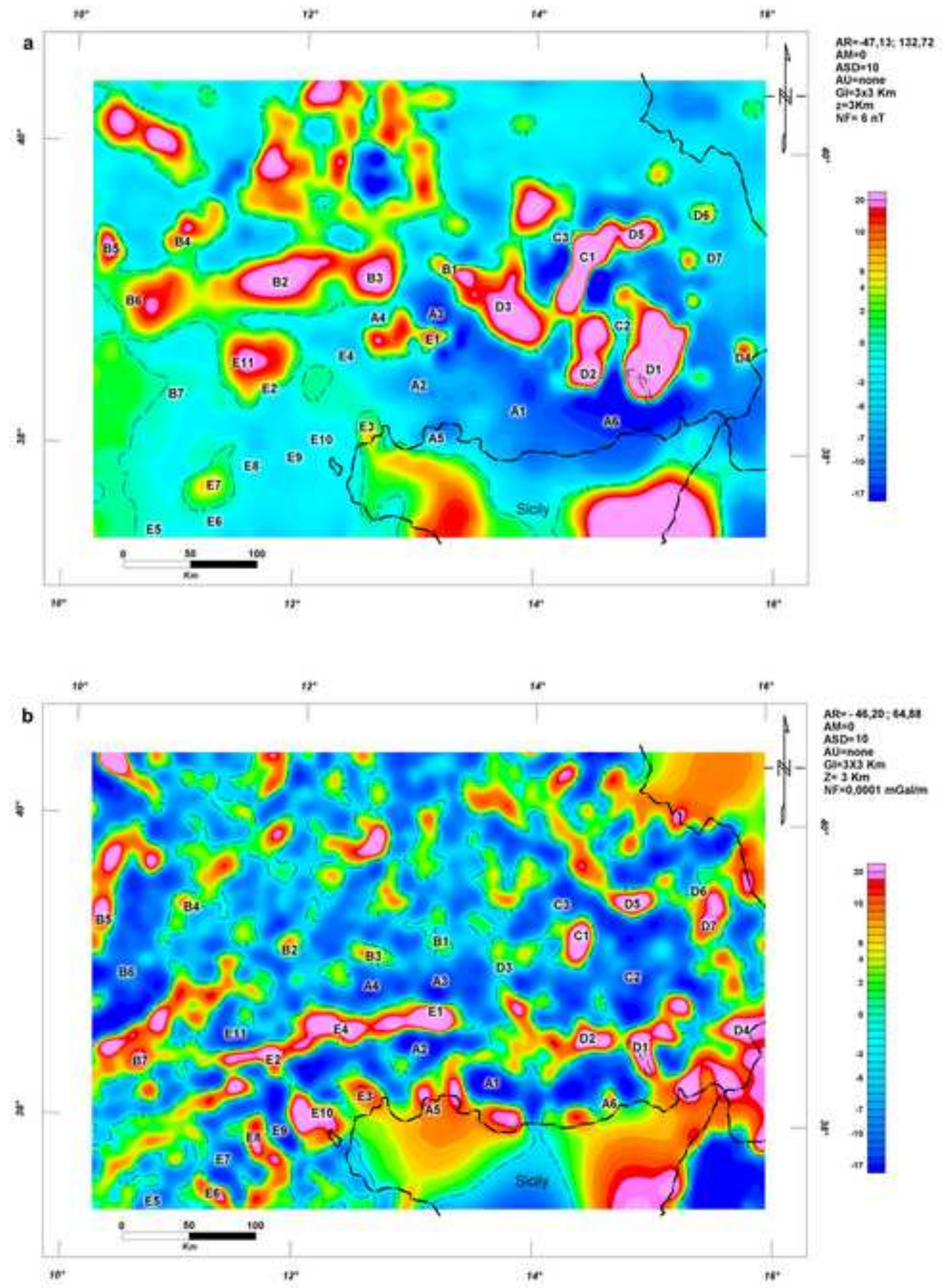


Figure(s)

Click here to download high resolution image

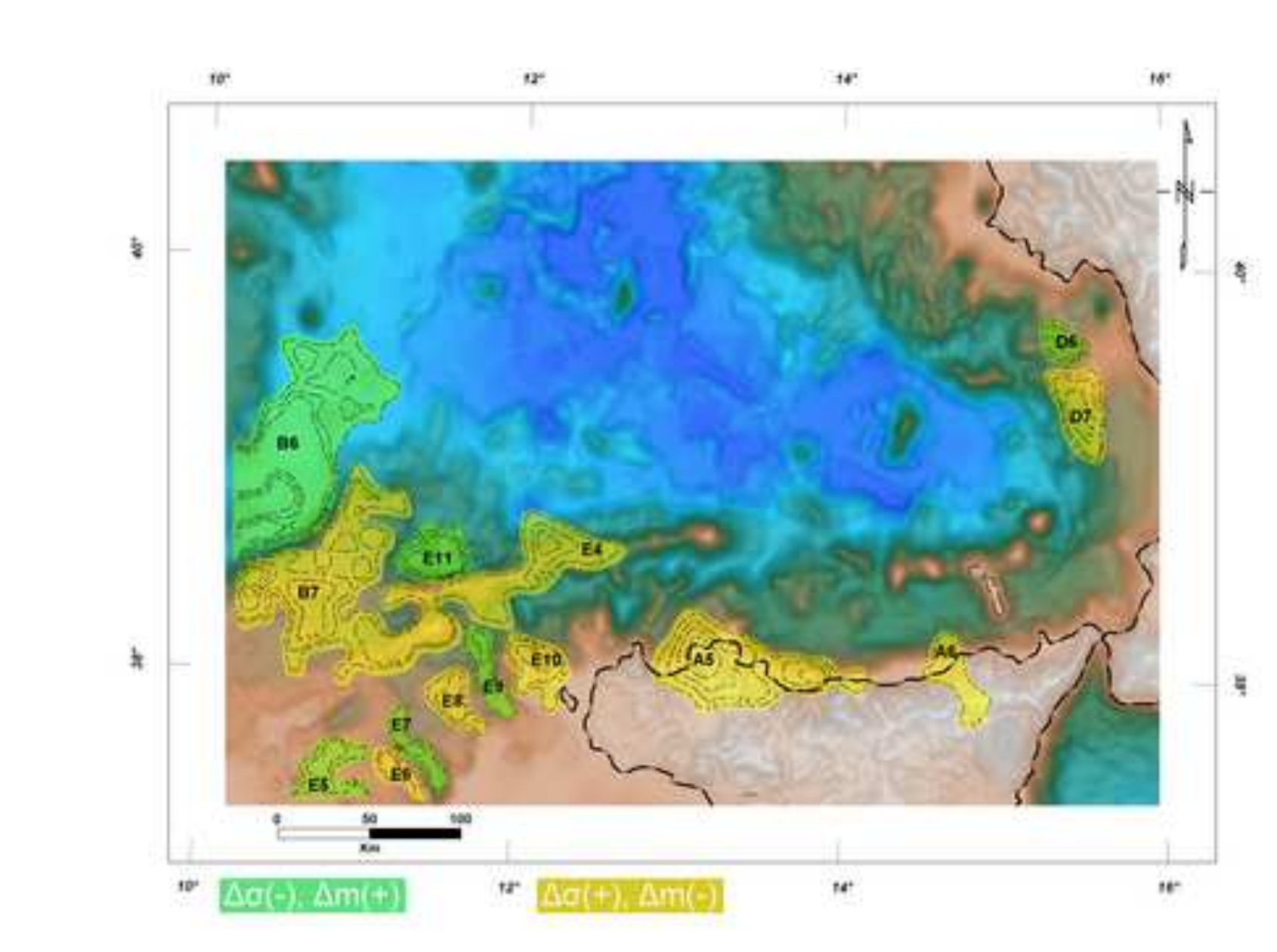

rage 32 of 34

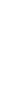


Table 1. Possible geological scenarios for interpreting correlative geopotential field anomalies of the Southern Tyrrhenian Sea. For each anomaly field, the signs in parentheses give the signs of the related physical property contrasts. For example, the Sicilian-Maghrebian nappes tend to be characterized by negative magnetization and positive density contrasts.

GRAVITY

$\Delta \sigma(+)$ $\Delta \sigma(-)$

\begin{tabular}{|c|c|c|}
\hline$\underset{\Xi}{ \pm}$ & $\begin{array}{l}\text { - calc-alkaline to shoshonitic volcanic } \\
\text { products of the Aeolian islands and } \\
\text { seamounts; } \\
\text { - oceanic to tholeiitic basalts of volcanic } \\
\text { islands and seamounts; } \\
\text { - pre-Tortonian carbonates; } \\
\text { - } \text { shallow intrusions; } \\
\text { - Bathymetricltopographic peaks }\end{array}$ & $\begin{array}{l}\text { sediments filling depressions of the } \\
\text { Sicilian-Maghrebian chain; } \\
\text { syn-rift Tortonian sediments of south } \\
\text { eastern Sardinia; } \\
\text { intrusions of sediment-filled basins. }\end{array}$ \\
\hline$\underset{\Xi}{\mathbb{E}}$ & $\begin{array}{l}\text { pelagic-to-terrigenous and Miocene } \\
\text { flysch-type nappes of the Sicilian- } \\
\text { Maghrebian chain. }\end{array}$ & $\begin{array}{l}\text { pelagic-to-terrigenous and Miocene flysch- } \\
\text { type nappes of the Sicilian-Maghrebian } \\
\text { chain; } \\
\text { sediments filling intra-slope depressions } \\
\text { bordering uplifted basement stacks; } \\
\text { sediments filling the peri-Tyrrhenian } \\
\text { basins surrounding the Aeolian islands and } \\
\text { northern Sicily; } \\
\text { reversely magnetized seafloor of the } \\
\text { eastern and western Marsili Basin on high } \\
\text { standing pre-Tortonian basement; } \\
\text { Bathymetricltopographic depressions. }\end{array}$ \\
\hline
\end{tabular}


Table 2. Correlative magnetic and gravity anomaly features listed by their alphanumeric identifiers (ID) and apparent positive ( + ) and negative (-) contrasts in magnetization $(\Delta \mathrm{m})$ and density $(\Delta \sigma)$. The related magnetic sources (MS) and gravity sources (GS) inferred for each physical property contrast are keyed to: 1 = topographic effects due the contrasts between the bathymetry/topography and water/air; 2 = terrain effects from contrasts within the terrain; and $3=$ deeper crustal contrasts.

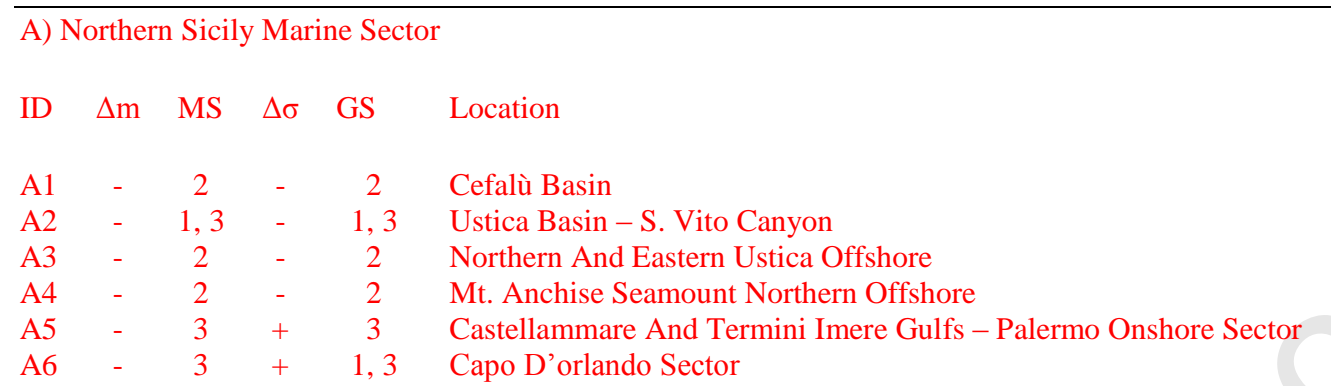

B) South Western Tyrrhenian Sea Sector

$\mathrm{B} 1+3+3$ Eastern Issel Basin

$\mathrm{B} 2+3+1 \quad$ Southern Magnaghi Basin

$\mathrm{B} 3+3+1$ Western Issel Basin

B4 +1 $+1,3$ South Western Mt. Majot Seamount Offshosre

B5 + $1+1$ Mt. Quirra Seamount Sector

B6 - $1+1$ Souhteastern Sardinia Offhsore

B7 + $1-1,2,3$ Panormed Promontory

C) Marsili Basin Sector

$\mathrm{C} 1+1+1$ Marsili Seamount

C2 - 3 - 3 South-Eastern Marsili Basin Plain Stromboli Canyon

C3 - 3 - 3 North-Western Marsili Basin Plain

D) Aeolian Islands Sector

D1 $+3,1+3,1 \quad$ Vulcano-Lipari-Salina, Panarea, Stromboli Islands

$\mathrm{D} 2+3,1+3,1 \quad$ Alicudi, Filicudi Islands

D3 + 3,1 $+3,1$ Western Aeolian Seamounts (Sisifo, Enarete)

$\mathrm{D} 4+3+3$ Tropea Offshore

D5 $+1,3+3$ Palinuro Seamount

D6 - $3+3$ Mt. Diamante Seamount

D7 $+3-3$ Paola Basin Sector

\section{E) Drepano-Elimi Sector}

$\begin{array}{cccccl}\text { E1 } & + & 3 & + & 1 & \text { Ustica Island Mt. Anchise Seamount } \\ \text { E2 } & + & 1,3 & + & 1 & \text { Aceste Seamount } \\ \text { E3 } & + & 3 & + & 3 & \text { Cofano Gulf Sector } \\ \text { E4 } & + & 3 & - & 3 & \text { Central Elimi Chain } \\ \text { E5 } & - & 1,3 & + & 1 & \text { Banco El Haquaria } \\ \text { E7 } & - & 3 & + & 1,3 & \text { Talbot Bank Sector } \\ \text { E9 } & - & 1,3 & + & 1,3 & \text { Isole Egadi Western Offhsore } \\ \text { E11 } & - & 3 & + & 1,3 & \text { Mt. Aceste Seamount Northern Offshore } \\ \text { E6 } & + & 1,3 & - & 1,3 & \text { Talbot Bank Sector } \\ \text { E8 } & + & 3 & - & 3 & \text { Isole Egadi Western Offhsore } \\ \text { E10 } & - & 1,3 & + & 1,3 & \text { Isole Egadi Western Offhsore }\end{array}$

